\title{
Estimating marine resource use by the American crocodile Crocodylus acutus in southern Florida, USA
}

\author{
Patrick V. Wheatley ${ }^{1,5, *}$, Hoyt Peckham ${ }^{2,3}$, Seth D. Newsome ${ }^{4}$, Paul L. Koch ${ }^{1}$ \\ ${ }^{1}$ Earth and Planetary Sciences Department, University of California, Santa Cruz, California 95064, USA \\ ${ }^{2}$ Grupo Tortuguero de las Californias, La Paz, Baja California Sur, 23060 Mexico \\ ${ }^{3}$ Center for Ocean Solutions, Stanford University, Monterey, California 93940 USA \\ ${ }^{4}$ Department of Zoology and Physiology, University of Wyoming, Laramie, Wyoming 82071, USA \\ ${ }^{5}$ Present address: Center for Isotope Geochemistry, Lawrence Berkeley National Laboratory, Berkeley, California 94720, USA
}

\begin{abstract}
Alligators and crocodiles differ in their physiological capacity to live in saline waters. Crocodiles can tolerate high-salinity water, at least for limited timeframes, whereas alligators and their close relatives cannot. Experiments have placed different crocodylians in various water salinities to document physiological responses, but no study has estimated the extent to which natural populations of crocodylids can live independent of fresh water. Here we estimated marine food and perhaps seawater contributions to a population of American crocodile Crocodylus acutus in southernmost Florida, USA. We evaluated the use of carbon, oxygen, and strontium isotopes as tracers of marine versus terrestrial sources. We compared C. acutus isotopic values to those of marine reptiles (marine iguanas and Pacific loggerhead turtles) and to American alligators, which require fresh water. We found that freshwater reptiles can be discriminated from those that drink seawater (or survive on metabolic and prey-included water in saline habitats) based on the magnitude of population-level oxygen isotope variation in bioapatite, whereas mean carbon isotope values discriminate between marine versus terrestrial food consumption. We used a 2 endmember (seawater and fresh water) mixing model to calculate percentage of marine resources used by $C$. acutus. Results indicate that adult $C$. acutus in southern Florida use marine food about $65 \%$ of the time and seawater or water gleaned from marine food about $80 \%$ of the time. This suggests that behavioral osmoregulatory techniques (i.e. seeking fresh water specifically for drinking, as suggested by other researchers) may not be necessary and that $C$. acutus is capable of being largely ecologically independent of fresh water.
\end{abstract}

KEY WORDS: Osmoregulation $\cdot$ Saltwater tolerance $\cdot$ Isotope $\cdot$ Reptile $\cdot$ Alligator $\cdot$ Marine iguana Sea turtle

\section{INTRODUCTION}

Researchers have been intrigued by the ability of some crocodylians to spend extended periods of time in waters with salinities as high as seawater. Among the 2 most diverse families in the Crocodylia, the
Crocodylidae are better adapted to salty environments than Alligatoridae (reviewed by Taplin 1988, Mazzotti \& Dunson 1989). This dichotomy has been demonstrated or inferred from differences in habitat use in the wild, from experiments, and based on their biogeography. With respect to habitat preferences, 
the crocodylids Crocodylus acutus and C. porosus are highly estuarine, and many other crocodylid species (e.g. C. catacphractus, C. johnstoni, C. moreletti, C. niloticus, and C. palustris), while typically associated with freshwater habitats, have estuarine populations (Taplin 1988, Mazzotti \& Dunson 1989, Jackson et al. 1996). In contrast, no alligatorid species typically inhabit estuarine environments, and only Alligator mississippiensis, Caiman crocodilus, and Caiman latirostris have some populations that frequent brackish habitats (Jackson et al. 1996, Grigg et al. 1998, Elsey 2005).

With respect to biogeographic differences, crocodylids occupy every continent that offers hospitable temperatures, whereas modern alligatorids nearly all inhabit the Americas. The exception is the Chinese alligator Alligator sinensis, which presumably crossed from North America to Asia over the Bering land bridge during the Eocene ( 56 to 34 Mya), when global temperatures were significantly higher than today (Brochu 2003). The limited biogeographic distribution of alligatorids applies to the fossil record as well (reviewed by Brochu 2000). This biogeography suggests that significant oceanic crossings are difficult or impossible for alligatorids, but unremarkable for crocodylids.

Physiological experiments have shown crocodylids to be especially suited for brackish and saline waters. Injection of a crocodylid with a methacholine chloride solution resulted in a hyperosmotic secretion via lingual salt glands (Taplin \& Grigg 1981). Some estuarine crocodylids refuse to drink seawater when dehydrated (Mazzotti \& Dunson 1984, Jackson et al. 1996); they only actively imbibe if water is less than 10 practical salinity units (psu). This often results in weight loss and/or dehydration for small fasted alligators kept in seawater (35 psu) under controlled settings (e.g. Dunson 1970, 1982, Evans \& Ellis 1977). Larger crocodiles could remain healthy for months in waters of 26 psu and higher if fed (Dunson 1970, 1982). Other experiments demonstrate that Crocodylus niloticus can tolerate salinities as high as 35 psu if salinity is increased gradually and the animals have time to adapt (Leslie \& Spotila 2000). Alligatorids have lingual glands that are stimulated by methacholine chloride injections, but their secretions are iso-osmotic with blood plasma and do not provide effective salt excretion (Taplin et al. 1985).

The adaptations of crocodylids to saline conditions (in particular the lingual salt glands) prompted Taplin et al. (1985) to suggest that crocodylids are derived from an ocean-going ancestor. Despite these adaptations, however, there is evidence that modern crocodylids are very much tied to fresh water. There is no modern example of pelagic/marine crocodylians and even though Crocodylus acutus and C. porosus are primarily estuarine, the other crocodylids are most often found in fresh water. Given this apparent dependence on fresh water, it is difficult to imagine a recent pelagic ancestor to Crocodylidae. In fact, Mazzotti \& Dunson (1989) argued that Crocodylus probably evolved saltwater adaptations the same way that turtles and snakes did, transitioning from fresh to estuarine, and finally seawaters. The evidence (physiology, ecology, biogeography) for adaptations to saltwater tolerance in Crocodylus is conspicuous, and the question of how tolerant natural populations are to saline waters remains open.

Results from several experiments imply that in natural conditions, adult crocodiles might be able to osmoregulate with very small amounts of low-salinity drinking water (Dunson 1970, 1982, Leslie \& Spotila 2000), but we are aware of no studies that have attempted to quantify the salinity of the water ingested by crocodylids in the wild. Observations of aquatic animals (especially those that can submerge for long periods of time) are difficult, and most observations made at specific field sites did not attempt to follow individuals to estimate the amount of time they spent in brackish (salinities 0.5 to $30 \mathrm{psu}$ ) versus saline waters (salinities 30 to $50 \mathrm{psu}$, with seawater averaging 35 psu). Kushlan \& Mazzotti (1989) compiled observational data for Crocodylus acutus in southern Florida (hereafter FL), USA, noting the number of sightings in waters of different salinity. Their data showed an overall preference for fresher water (average salinity $=14 \mathrm{psu}$ ), but substantial numbers of individuals were seen in higher-salinity water. The number of sightings in higher-salinity waters (average $=17.8 \mathrm{psu}$ ) increased during the nesting season (March to August), when individuals were more commonly observed on the shoreline along Florida Bay, where nesting sites are common. That study estimated time spent in different salinity waters but did not attempt to estimate ingestion of marine resources (food and water).

Radio- or satellite-tracking is increasingly being used to study animal habitat preferences and migration. However, studies of taxa with estuarine adaptations have largely been limited to freshwater populations of those species (e.g. Rodda 1984, Brien et al. 2008) with some exceptions. Read et al. (2007) focused on the homing abilities of translocated individuals of Crocodylus porosus, but their study is not applicable to discerning the proportion of time spent in fresh versus saline water. Kay (2004) studied 16 
C. porosus to discern preferred habitats and home ranges. The relative proportions of time spent in each salinity zone were not explicitly discussed, but the data suggest that the time spent in each zone is highly variable from individual to individual. Kushlan \& Mazzotti (1989) focused on C. acutus in southern FL, using observational data (see above) and telemetry data from 10 individuals to better understand nesting ecology, but they did not tie their data to salinity gradients.

Determining the habitats in which crocodylians are feeding or drinking observationally is even more difficult. Although there may be cues associated with some feeding behaviors, it is challenging to determine by observation whether an aquatic animal is drinking the water in which it is immersed. Such problems have been addressed using tracers (natural or artificial) to track the source of an animal's food and water inputs. Here, we used stable isotope ratios of carbon, oxygen, and strontium ( $\mathrm{Sr}$ ) in biological apatite, the mineral in bones and teeth, as natural tracers to estimate the amount of marine resources used by the crocodylid Crocodylus acutus in southern FL. We compared the isotope ratios of C. acutus to those of 2 fully marine reptiles (marine iguanas Amblyrhynchus cristatus and Pacific loggerhead turtles Caretta caretta). We further compared C. acutus to the alligatorid Alligator mississippiensis, an obligate freshwater drinker (Laurén 1985), with similar opportunistic generalist feeding ecology (McNease \& Joanen 1977, Thorbjarnarson 1988a) and similar home range requirements (Joanen \& McNease 1989, Kushlan \& Mazzotti 1989, Cherkiss et al. 2011), in both inland/freshwater and coastal ecosystems. Before presenting our analysis, we offer a brief overview of the isotopic systems we used and what aspects of animal ecology and physiology they record.

\section{Carbon isotope ratios in bioapatite}

Carbon in biological hydroxyapatite (or bioapatite), $\mathrm{Ca}_{5}\left(\mathrm{PO}_{4}, \mathrm{CO}_{3}\right)_{3}\left(\mathrm{OH}, \mathrm{CO}_{3}\right)$ is derived from blood bicarbonate, which in air-breathing terrestrial animals is supplied by the oxidation of food (i.e. respiration). In mammals, the carbon isotope $\left(\delta^{13} \mathrm{C}\right)$ value of bioapatite is tightly correlated with that of bulk diet, offset by a trophic discrimination ( $9 \%$ o for carnivores, $\sim 14 \%$ o for herbivores; reviewed by Koch 2007). Differences in the $\delta^{13} \mathrm{C}$ value of primary producers cascade up food webs with small ${ }^{13} \mathrm{C}$ enrichments ( $+1 \%$ o per trophic step) to label large carnivores such as crocodylians. Clementz \& Koch (2001) showed that bioapatite $\delta^{13} \mathrm{C}$ values from mammals are useful in identifying the different marine, estuarine, and terrestrial ecosystems in which animals forage.

Carbon fixation by primary producers sorts carbon isotopes in different but predictable ways. Plants using the $\mathrm{C}_{3}$ photosynthetic pathway in terrestrial and freshwater ecosystems (trees, shrubs, cool growing season grasses) average $\sim 27 \%$. $\mathrm{C}_{4}$ plants (warm growing season grasses) average $-12 \%$, and CAM plants (some succulents) have variable values between -27 and $-11 \%$ (reviewed by Farquhar et al. 1989). Marine $\delta^{13} \mathrm{C}$ values vary with the source of carbon, photosynthetic processes, and other factors (reviewed by Newsome et al. 2010). Macroscopic marine plants have higher $\delta^{13} \mathrm{C}$ values (i.e. kelp averages $\sim-17 \%$, seagrass averages $\sim 10 \%$ ), whereas marine phytoplankton has lower values of -20 to $-26 \%$, depending on oceanographic setting and plankton type (Clementz \& Koch 2001, Page et al. 2008). River ecosystems contain carbon both from autochthonous aquatic $\left(\mathrm{C}_{3}\right)$ sources $(\sim-27 \%$ ) and allochthonous terrestrial sources $\left(\mathrm{C}_{3}\right.$ or $\mathrm{C}_{4}$ vegetation) from riverbanks ( -27 to $\sim-13 \%$; reviewed by Fry \& Sherr 1984, Doi 2009). Estuaries mix river and marine waters, and the sources of carbon can be allochthonous or autochthonous, but autochthonous $\delta^{13} \mathrm{C}$ values in estuarine habitats are higher than in freshwater rivers due to the marine influence (e.g. Silva et al. 2011).

We know of only 2 papers that have analyzed bioapatite $\delta^{13} \mathrm{C}$ values to study modern reptiles. Smith et al. (2002) presented a straightforward comparative study of the diets of terrestrial mammals, birds, and lizards in the Chihuahuan Desert. The situation is more complex for ectotherms living in water, which is relatively rich in dissolved inorganic carbon (DIC), a potential alternate source of carbon to blood bicarbonate. Biasatti (2004) studied bone bioapatite $\delta^{13} \mathrm{C}$ values in sea turtles. She found large differences in diet-to-apatite fractionation among taxa and across space within taxa, which she attributed to differences in the labeling of bone carbonate by respired carbon versus seawater DIC. She did not exclude an alternate hypothesis, that differences in digestive physiology between herbivorous and carnivorous turtles could explain the observed pattern. However, in a study of entirely carnivorous (though not air-breathing) sharks, Vennemann et al. (2001) also detected large differences in bioapatite $\delta^{13} \mathrm{C}$ values that they attributed to differences in labeling by respired carbon versus seawater DIC. 


\section{Oxygen isotope ratios in bioapatite}

The oxygen isotope $\left(\delta^{18} \mathrm{O}\right)$ value of bioapatite depends on the temperature at which the mineral forms and the $\delta^{18} \mathrm{O}$ value of the body fluid from which it precipitates (reviewed by Kohn \& Cerling 2002, Koch 2007). The $\delta^{18} \mathrm{O}$ value of body water is influenced by ingested water (which differs among potential sources, such as food versus drinking water) and the input of food oxygen and inspired $\mathrm{O}_{2}$ via respiration, and by the physiology of water turnover and economy (Kohn 1996). Aquatic ectotherms, such as crocodylians, form bioapatite from body water that is close in $\delta^{18} \mathrm{O}$ value to environmental water at a temperature close to ambient. Wild alligator bone phosphate $\delta^{18} \mathrm{O}$ values are consistent with those expected given environmental temperatures (Stoskopf et al. 2001). In wild and captive crocodylians, Amiot et al. (2007) correlated phosphate $\delta^{18} \mathrm{O}$ values to those of ambient water $\left(\mathrm{R}^{2}=0.84\right)$, and attributed residual variation to differences in temperature, diet, and/or physiology. Overall, we expect the $\delta^{18} \mathrm{O}$ value of an aquatic reptile to reflect the $\delta^{18} \mathrm{O}$ value of the water it ingests, either by drinking or in the fluids or metabolic water from diet items.

Coastal ocean water in tropical and subtropical regions has a fairly constant $\delta^{18} \mathrm{O}$ value close to $0 \%$ o (LeGrande \& Schmidt 2006). Meteoric water $\delta^{18} \mathrm{O}$ values, in contrast, vary with latitude, altitude, and distance from the evaporative source. Precipitation and surface water in the tropics is typically ${ }^{18} \mathrm{O}$-depleted relative to ocean water by up to $5 \%$, although values greater than $0 \%$ can occur in tropical and subtropical surface waters that experience strong evaporative water loss (reviewed by Gat 1996). These isotopic differences between fresh water and seawater, and the fact that they are recorded in bioapatite, have been used to study habitat use and drinking water sources in aquatic and semi-aquatic fossil vertebrates (Thewissen et al. 1996, 2007, Roe et al. 1998, Clementz et al. 2003, 2006, BillonBruyat et al. 2005, Amiot et al. 2010).

\section{Sr isotope ratios in bioapatite}

Sr in bioapatite occurs as a substitution for calcium. Assuming biological fractionation of Sr is negligible (Capo et al. 1998), $\mathrm{Sr}$ incorporated into bioapatite will reflect the bioavailable $\mathrm{Sr}$ derived from the soil (or water) of an animal's environment (reviewed by Bentley 2006, Koch 2007). For animals such as crocodiles, which ingest and dissolve calcium-rich bone, the dominant source of $\mathrm{Sr}$ will be diet and not ingested water.

Similar to carbon and oxygen, variations in the ${ }^{87} \mathrm{Sr} /{ }^{86} \mathrm{Sr}$ ratio of animals are controlled by the mixing of isotopically distinct sources. Environmental ${ }^{87} \mathrm{Sr} /{ }^{86} \mathrm{Sr}$ ratios can differ geographically due to regional differences in geologic substrate, whereas seawater has a relatively uniform ${ }^{87} \mathrm{Sr} /{ }^{86} \mathrm{Sr}$ ratio ( 0.7092), although this marine value varies on a geological timescale (Burke et al. 1982). Animals feeding exclusively in a marine ecosystem should have ${ }^{87} \mathrm{Sr} /{ }^{86} \mathrm{Sr}$ values similar to that of seawater. Therefore, these taxa can be distinguished from those feeding in (or inhabiting) terrestrial or estuarine ecosystems (e.g. Koch et al. 1992, Schmitz et al. 1997, Poyato-Ariza et al. 1998, Kennedy et al. 2002, Clementz et al. 2003. Price \& Gestsdóttir 2006, Kocsis et al. 2007).

\section{MATERIALS AND METHODS}

\section{Samples}

We sampled 4 species of reptile: the crocodylians Alligator mississippiensis and Crocodylus acutus, and the marine reptiles Amblyrhynchus cristatus and Caretta caretta. C. acutus specimens were collected in southern FL (Fig. 1) and curated by the Florida Museum of Natural History at the University of

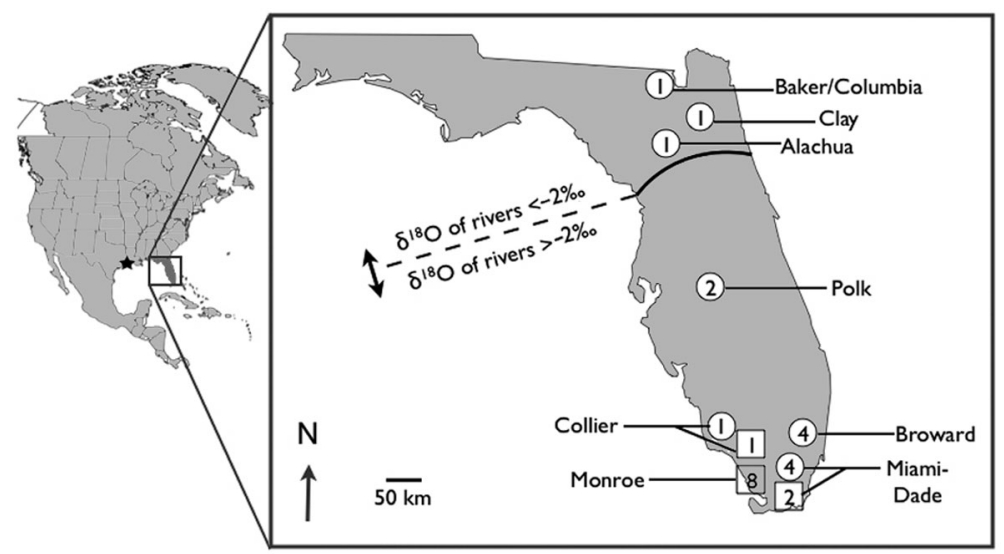

Fig. 1. Localities where crocodylians were sampled from Florida and Louisiana, USA. Contour line from Kendall \& Coplen (2001) that separates river waters with $\delta^{18} \mathrm{O}$ values $>-2 \%$ from those $<-2 \%$. Numerals in circles represent the number of alligators sampled from that county; numerals in squares represent the number of crocodiles sampled in that county. $\star$ : location of Rockefeller Wildlife Refuge (RWR) 
Florida (UF). Care was taken not to select samples of C. acutus from the Turkey Point nuclear power station canal. The effluent water from the power plant is artificially warm, and we were concerned about the effects on the isotopic composition of bioapatite carbonate from these individuals. A. mississippiensis specimens were collected in FL (Fig. 1) and at the Rockefeller Wildlife Refuge (RWR) in Louisiana (hereafter LA). These specimens were divided into those that were collected in coastal habitats and those that were collected at inland sites $(>16 \mathrm{~km}$ from the coast, i.e. farther than the typical home range of A. mississippiensis; Joanen \& McNease 1989).

Crocodylus acutus and UF-curated Alligator mississippiensis are identified by UF museum numbers, and some additional information on these specimens may be available through the Florida Museum of Natural History. These animals are all adults, although sex for most individuals is unknown. Most of the UF crocodylians were collected in the 1980s. Less information is available for the RWR animals. Most of the RWR A. mississippiensis specimens are represented only by teeth, and in most cases the sex of the animal and accurate size information are not available. Most animals were estimated to be adults in a field setting by RWR staff. Body length measurements where available (4 non-adults and several adults) are reported in Table A1 in Appendix 1. The RWR crocodylians were collected between 2005 and 2009. 'UW' numbers are uncataloged specimens at the University of Wyoming Geological Museum. These specimens are teeth only, and no size data exist, but tooth sizes are consistent with sub-adults or small adults from RWR.

Marine iguana Amblyrhynchus cristatus specimens were collected from the Galapagos Islands and curated by the California Academy of Sciences (CAS). Loggerhead turtles Caretta caretta were col- lected in Baja California Sur, Mexico, and are curated by the Long Marine Laboratory (LML) at the University of California, Santa Cruz (UCSC). Locality information and number of individuals analyzed are reported in Table 1. We analyzed teeth or bone samples from 5 individuals as a minimum population size to determine mean isotopic values and standard deviations that accurately reflect the variability in a natural population (Clementz \& Koch 2001).

For the 2 crocodylians and the marine iguana, tooth enamel and dentine were combined for isotopic analysis of the carbonate fraction of tooth mineral bioapatite. We expect similar mean values and variability in tooth enamel and dentine because they contain the same mineral phase and form in the same narrow temporal window ( 10 mo for tooth formation; Edmund 1962). We studied teeth because ultimately we will use our results to inform studies of fossil material, and tooth enamel is much more resistant to post-mortem alteration than other biogenic tissues (Wang \& Cerling 1994, Koch et al. 1997). Although we used both enamel and dentine for this study, fossil workers should take care to use only enamel because dentine is highly subject to diagenetic alteration. Because sea turtles are edentulous, we used bone from the humerus. Mean values for bone apatite carbonate should be directly comparable to those for tooth enamel and dentine. Bone tissue is deposited in concentric layers in turtle bones and turns over slowly (De Ricqlés 1976, Butcher et al. 2008). If only one growth increment is subsampled and analyzed, then variability between bone and teeth might be roughly equivalent. However, if bone is homogenized and analyzed, then bone samples represent a much longer time interval than does a single reptile tooth. Our turtle bone samples were homogenized and thus they likely have lower intrinsic variability than reptile tooth samples.

Table 1. Stable isotope means (\%o relative to V-PDB) and standard deviations of carbonate in bioapatite in teeth (bone in the case of loggerhead turtles Caretta caretta) of the reptile specimens used in this study. CAS: California Academy of Sciences; UCSC: University of California, Santa Cruz; UF: University of Florida; RWR: Rockefeller Wildlife Refuge (Louisiana); na: not available

\begin{tabular}{|c|c|c|c|c|c|}
\hline Species & $\mathrm{n}$ & General locality & Institution & $\delta^{13} \mathrm{C}$ & $\delta^{18} \mathrm{O}$ \\
\hline Amblyrhynchus cristatus & 5 & Galapagos Islands & CAS & $-4.2 \pm 2.2$ & $-0.8 \pm 0.6$ \\
\hline Caretta caretta & 31 & Baja California & Long Marine Lab (UCSC) & $-9.0 \pm 0.6$ & $1.3 \pm 0.6$ \\
\hline Dermochelys coriacea $^{\mathrm{a}}$ & 5 & Guyana and Florida & na & $-9.6 \pm 2.2$ & na \\
\hline Crocodylus acutus & 9 & Southern Florida & UF & $-9.6 \pm 3.9$ & $0.5 \pm 0.8$ \\
\hline Alligator mississippiensis (coastal) & 16 & Florida and Louisiana & RWR \& UF & $-10.3 \pm 2.6$ & $-0.9 \pm 1.7$ \\
\hline Alligator mississippiensis (inland) & 12 & Florida & UF & $-15.7 \pm 1.8$ & $-0.2 \pm 2.2$ \\
\hline
\end{tabular}




\section{Isotopic analysis}

Approximately $10 \mathrm{mg}$ of powder were drilled from each alligator tooth. For the marine iguanas, a single whole tooth was used, and $\sim 20 \mathrm{mg}$ of bone were drilled from the loggerhead turtle humeri. The powdered samples were soaked in $30 \% \mathrm{H}_{2} \mathrm{O}_{2}$ for $48 \mathrm{~h}$ to oxidize organic matter. They were then rinsed 5 times with distilled water and soaked for $24 \mathrm{~h}$ in $1 \mathrm{M}$ calcium acetate/acetic acid buffer solution ( $\mathrm{pH}$ ) to remove carbonate contaminants. Finally, the powdered samples were rinsed 5 times in distilled water and freeze dried. Marine iguana teeth were soaked for $48 \mathrm{~h}$ in $30 \% \mathrm{H}_{2} \mathrm{O}_{2}$ then freeze dried. Whole tooth samples were not soaked in acetic acid due to fears of sample loss. The whole tooth samples were taken from wild-caught marine iguanas, and $30 \% \mathrm{H}_{2} \mathrm{O}_{2}$ has a pH of $\sim 5$, so carbonate contamination is unlikely.

For each analysis, $\sim 1.5 \mathrm{mg}$ of pre-treated powder, or a whole individual tooth, were used. Analyses were conducted on an ISOCARB carbonate preparation system linked to either a Micromass Optima or Prism gas source isotope ratio mass spectrometer in the Stable Isotope Laboratory at UCSC. During analysis, samples were dissolved in a continuouslystirred, common acid bath containing $100 \%$ phosphoric acid at $90^{\circ} \mathrm{C}$. Reaction time was $800 \mathrm{~s}$, and to reduce sample-to-sample memory, blanks were run between samples. The resulting $\mathrm{CO}_{2}$ was cryogenically purified and then admitted to the mass spectrometer for analysis. The inter-lab isotope standard was NBS-19, our internal standard was Carrera Marble, and values are reported relative to Vienna PeeDee Belemnite (V-PDB). We also used a bioapatite internal standard of elephant dentine $(n=9$, for both $\delta^{13} \mathrm{C}$ and $\delta^{18} \mathrm{O}$; for the bioapatite standard, $1 \mathrm{SD}$ is $\pm 0.3 \%$ ) .

For Sr isotope analysis, $\sim 1 \mathrm{mg}$ of drilled dental powder was dissolved in $\sim 2.5 \mathrm{~N} \mathrm{HCl}$ and concentrated $\mathrm{HNO}_{3}$, then evaporated to dryness on a hot plate. The samples were redissolved in $2.5 \mathrm{M} \mathrm{HCl}$, and $\mathrm{Sr}$ was isolated using Teflon shrink tubing cation exchange columns packed with Eichrom Sr Spec resin. The elutant was collected and dried down on a hot plate. Samples were redissolved in $2 \% \mathrm{HNO}_{3}$, and $\mathrm{Sr}$ concentration was adjusted to $100 \mathrm{ppm}$. Sr isotope composition was measured at the Keck Isotope Laboratory at UCSC on a Finnigan Neptune multicollector inductively coupled plasma mass spectrometer (ICP-MS) at low resolution. Corrections were made for interfering $\mathrm{Kr}$ masses. Results were normalized to the international standard, NIST 987, and precision was calculated to be better than 0.00005 (1 SD).
Carbon isotope values were calculated using the following formula:

$\delta^{13} \mathrm{C}=\left[\left({ }^{13} \mathrm{C} /{ }^{12} \mathrm{C}_{\text {sample }} \div{ }^{13} \mathrm{C} /{ }^{12} \mathrm{C}_{\text {standard }}\right)-1\right] \times 1000$

where the standard is $\mathrm{V}-\mathrm{PDB} . \delta^{18} \mathrm{O}$ values were calculated using the same convention, but the isotopic ratio is ${ }^{18} \mathrm{O} /{ }^{16} \mathrm{O}$. Units are reported in parts per thousand (\%). In the case of $\mathrm{Sr}$, the isotope ratio $\left({ }^{87} \mathrm{Sr} /{ }^{86} \mathrm{Sr}\right)$ is reported rather than normalizing to a standard.

Because crocodylians replace their teeth continuously, it is possible that analysis of multiple teeth from 1 individual could supply as much information about a population as analysis of a single tooth from multiple individuals, assuming that the individual behaved in a manner that was representative of the population as a whole. We tested this possibility by analyzing multiple teeth from 1 Alligator mississippiensis and comparing the variance in both $\delta^{13} \mathrm{C}$ and $\delta^{18} \mathrm{O}$ values to the variance of 14 individuals from the same population. Multiple teeth from the same individual had significantly less variability than the population as a whole for both $\delta^{13} \mathrm{C}$ and $\delta^{18} \mathrm{O}$ values, leading us to conclude that for isotopic analyses, it is not reasonable to bolster sample size by treating multiple teeth from a single animal with the same weight as a tooth from a different individual (see Appendix 2).

\section{RESULTS AND DISCUSSION}

Mean carbon and oxygen isotope values and associated standard deviations for all reptile groups are reported in Table 1 and Fig. 2.

\section{Marine reptiles}

Pacific loggerhead turtles forage in the eastern Pacific but nest on Japanese or Australian beaches (although the vast majority of the loggerheads off Baja California, where our study samples were collected, nest in Japan; Bowen et al. 1995). Loggerheads are generally carnivorous and may feed at high trophic levels compared to other genera of sea turtles (Godley et al. 1998, Frick et al. 2009).

Pacific loggerhead turtle bone carbonates have a mean $\delta^{18} \mathrm{O}$ value near $0 \%$ and low standard deviation $(1.3 \pm 0.6 \%$ o, which is expected for an animal that gets water and food entirely from the sea (see discussion about the significance of population $\delta^{18} \mathrm{O}$ variance below). Pacific loggerhead $\delta^{13} \mathrm{C}$ values $($ mean $=-9.0 \pm 0.6 \%$ o) are similar to values for bone 


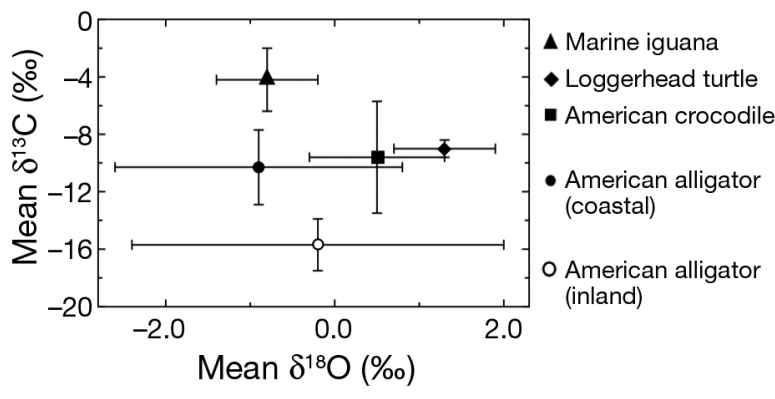

Fig. 2. $\delta^{13} \mathrm{C}$ and $\delta^{18} \mathrm{O}$ values (mean $\pm \mathrm{SD}$ ) for the reptiles sampled in this study (marine iguana Amblyrhynchus cristatus, loggerhead turtle Caretta caretta, American crocodile Crocodylus acutus, and American alligator Alligator mississippiensis). Note relatively high $\delta^{13} \mathrm{C}$ values of species with access to marine food webs

carbonate from marine carnivorous leatherback turtles, which forage in the Atlantic Ocean and the Gulf of Mexico, from a previous study (Biasatti 2004).

Marine iguanas live exclusively in the Galapagos Islands and have an amphibious lifestyle, basking on land but drinking and foraging in seawater (Carpenter 1966, Shoemaker \& Nagy 1984). Similar to the Pacific loggerhead samples, marine iguanas have relatively invariant $\delta^{18} \mathrm{O}$ values near $0 \%$ o $(-0.8 \pm$ $0.6 \%)$, consistent with seawater ingestion and marine foraging. Marine iguanas are herbivorous, feeding almost exclusively on marine brown and red algae (Wikelski et al. 1993). The $\delta^{13} \mathrm{C}$ values of marine algae can vary widely. Kelps can have very high $\delta^{13} \mathrm{C}$ values $(\sim-12 \%)$, whereas intertidal red algae can have extremely low values ( $-30 \%$; Raven et al. 2002). Marine iguana tooth bioapatite carbonate ranged from -9.6 to $-0.3 \%$ o (mean $=-4.2 \pm 2.2 \%$ ). Values near $0 \%$ likely indicate high reliance on kelp, whereas lower values could be a mix of kelp and red algae. In herbivorous mammals, ${ }^{13} \mathrm{C}$-enrichment in bone and tooth carbonate relative to diet can be higher than in carnivores, due to loss of ${ }^{13} \mathrm{C}$-depleted methane during gut fermentation of plant material (Hedges 2003, Clementz et al. 2009). Although this phenomenon has not been documented in reptiles, it may be a factor in explaining the high $\delta^{13} \mathrm{C}$ values in marine iguanas.

\section{Spatial gradients in crocodylians}

We compared isotopic values for saltwater tolerant Crocodylus acutus to obligate freshwater drinking Alligator mississippiensis in similar environments. When comparing $\delta^{13} \mathrm{C}$ and $\delta^{18} \mathrm{O}$ values of $C$. acutus to all $A$. mississippiensis, it is appropriate to use a mul- tivariate analysis of variance (MANOVA) because $\delta^{13} \mathrm{C}$ and $\delta^{18} \mathrm{O}$ values generally covary. When analyzed for differences by taxon, significant differences were found between $C$. acutus and all A. mississippiensis $\left(F_{2,34}=4.8, \mathrm{p}=0.0148\right)$. Results for $C$. acutus versus the alligators split into different ecological zones (inland and coastal) were also calculated (MANOVA, Pillai's Trace Test; approximate $F_{4,68}=7.6, \mathrm{p}<$ 0.0001). Post hoc pairwise comparisons found that the multivariate mean for saltwater-tolerant (marine/ estuarine) $C$. acutus is significantly higher than for the inland $\left(F\right.$-test; $\left.F_{2,33}=13.9, \mathrm{p}<0.0001\right)$ but not the coastal $A$. mississippiensis populations $\left(F\right.$-test; $F_{2,33}=$ 2.3, $\mathrm{p}=0.1172$ ). Multivariate means for A. mississippiensis from coastal settings are significantly higher than those from inland settings (MANOVA $F_{2,33}=$ 13.0, $\mathrm{p}<0.0001$ ).

When Alligator mississippiensis is split into inland and coastal populations, the covariance is removed. Based on mean $\delta^{13} \mathrm{C}$ values, coastal A. mississippiensis and Crocodylus acutus are not significantly different (Table 1), indicating that $\delta^{13} \mathrm{C}$ and $\delta^{18} \mathrm{O}$ do not covary in this smaller subset of the data, so MANOVA is no longer required. A simple $t$-test between the mean $\delta^{18} \mathrm{O}$ values of the 2 groups indicates that coastal A. mississippiensis have a significantly lower mean value than $C$. acutus $\left(t_{22.8}=-2.9\right.$, $\mathrm{p}=0.009$ ). The similarity in $\delta^{13} \mathrm{C}$ values between coastal alligators and crocodiles indicates that they have comparable amounts of marine carbon in their diets. The difference in $\delta^{18} \mathrm{O}$ values among crocodylian groups is more difficult to interpret, with latitude, precipitation, and evaporation all potentially playing a role.

We expected that seawater ingestion (either directly or via water in food and metabolic water) would yield higher $\delta^{18} \mathrm{O}$ values than freshwater consumption. However, the inland population of Alligator mississippiensis has a mean $\delta^{18} \mathrm{O}$ value that is not significantly different than the mean for saltwaterdrinking marine iguanas $(p=0.61)$. A possible explanation is that some inland alligators may ingest water that is ${ }^{18} \mathrm{O}$-enriched relative to precipitation by evaporation. Inland water sources in central and southern FL may have values of up to $+4 \%$, whereas the amount-weighted mean annual $\delta^{18} \mathrm{O}$ of precipitation is -2.7 to $-2.5 \%$ o (Meyers et al. 1993, Gremillion \& Wanielista 2000).

Mean $\delta^{18} \mathrm{O}$ values from coastal and inland populations of Alligator mississippiensis are not significantly different $(\mathrm{p}=0.35)$, which might be expected for freshwater consumers, but a latitudinal difference in sampling sites complicates this interpretation. 
With 1 exception, our coastal alligators are from LA, whereas the majority of our inland alligators are from southern FL. The meridional change in precipitation $\delta^{18} \mathrm{O}$ values across the region results in river waters in northern FL and southern LA that are $2 \%$ lower than in southern FL (Kendall \& Coplen 2001), and this difference may be transmitted to crocodylian bioapatite carbonate, assuming growth occurs at similar temperatures in both sites. If animals grow at lower temperatures at northern sites (LA sites average $5^{\circ} \mathrm{C}$ cooler than southern FL sites), the increase in water-to-apatite oxygen isotope fractionation with decreasing temperature, $\sim 1 \%$ o per $5^{\circ} \mathrm{C}$ (Friedman \& $\mathrm{O}^{\prime}$ Neil 1977), would partially offset this difference in environmental water.

To explore possible latitudinal effects, we divided inland FL alligators into northern and southern subsets based upon the Kendall \& Coplen (2001) contour line separating river waters with $\delta^{18} \mathrm{O}$ values $>-2 \%$ from those $<-2 \%$ (Fig. 1). The southern FL inland alligators have mean $\pm \mathrm{SD} \delta^{18} \mathrm{O}$ value of $0.2 \pm 2.2 \%$ $(\mathrm{n}=9)$, and northern FL inland alligators have a mean of $-1.4 \pm 1.8 \%$ o $(\mathrm{n}=3)$. The means are not significantly different $\left(t_{4.2}=-1.3, \mathrm{p}=0.25\right)$, but our northern FL sample is small, and the $\sim 2 \%$ difference we observed is of the expected magnitude and sign given the difference between northern and southern FL river water $\delta^{18} \mathrm{O}$ values. Coastal alligators from RWR (which receives precipitation of roughly the same $\delta^{18} \mathrm{O}$ value as northern FL) average $-0.9 \pm$ $1.6 \%$, not significantly different from northern FL inland alligators $\left(t_{2.8}=0.5, \mathrm{p}=0.68\right)$. The sole coastal alligator sample from southern FL had a $\delta^{18} \mathrm{O}$ value of -0.4 , well within the range of values for coastal LA as well as southern FL inland alligators but about $1 \mathrm{SD}$ lower than the Crocodylus acutus mean (Table 1).

Our results suggest that mean $\delta^{18} \mathrm{O}$ values are of limited use as an ecological tracer in our study area. In our data, a combination of latitudinal and evaporative differences in isotopic composition of precipitation and river water is likely driving the trends in $\delta^{18} \mathrm{O}$ values. Thus, we cannot separate organisms that obtain their water from the sea from those that drink fresh water in southern FL based on mean $\delta^{18} \mathrm{O}$ values. At higher latitudes (where the difference in the $\delta^{18} \mathrm{O}$ value between fresh water and seawater is larger), mean $\delta^{18} \mathrm{O}$ values may be a useful measure of the extent to which a vertebrate ingests seawater or obtains food and metabolic water from the sea.

While differences in mean $\delta^{18} \mathrm{O}$ values show limited utility in discriminating between alligators and crocodiles where they co-occur in southern FL, there are differences in standard deviations among taxa
(Table 1, Fig. 3). Animals that drink seawater or ingest seawater via prey body water (marine iguanas, sea turtles, and crocodiles) have low $\delta^{18} \mathrm{O}$ variability, whereas coastal and inland alligators show significantly higher variability (Table 1 ). This relationship is similar to that observed by Clementz \& Koch (2001) for terrestrial versus aquatic mammals. Reptiles that drink seawater ingest a source that is isotopically homogeneous, providing an input to body water (and thus bioapatite) with a relatively constant $\delta^{18} \mathrm{O}$ value. Even if food-included water and metabolic water from marine food items contribute to body water, these sources will have $\delta^{18} \mathrm{O}$ values that will be more homogeneous than those of terrestrial or freshwater prey. Note that the marine iguana tooth $\delta^{18} \mathrm{O}$ SD is as small as the SD for loggerhead turtle bone (Table 1, Figs. $2 \& 3$ ), which is integrated over a longer time period than teeth (and thus averages out short-term changes in temperature or water source). In contrast, many terrestrial water sources vary latitudinally and seasonally, or based on differences in source (recent precipitation versus groundwater).

Coastal alligators from RWR, inland alligators from northern FL, and inland alligators from southern FL all exhibit similar variance (Levene test for unequal variance $F_{2,24}=0.43, \mathrm{p}=0.65$ ). We conclude that use of seawater (directly or via diet) by Crocodylus acutus has significantly reduced its $\delta^{18} \mathrm{O}$ variation in comparison to the freshwater-drinking alligators $\left(F_{26,8}=0.17, \mathrm{p}=0.014\right)$.

We expected that $\delta^{13} \mathrm{C}$ values would vary inversely with distance to the coast, such that high carbon isotope values were expected when marine resources were consumed and low values when terrestrial/ freshwater resources were consumed. Even if DIC plays a significant role in labeling crocodylian bioap-

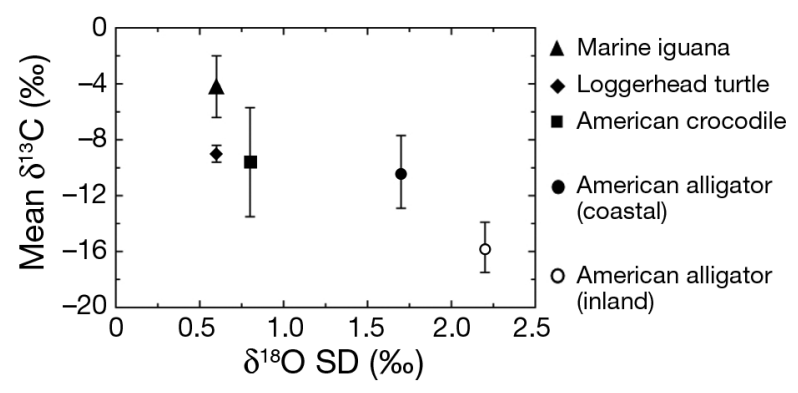

Fig. 3. Mean $\delta^{13} \mathrm{C}$ value versus the standard deviation of $\delta^{18} \mathrm{O}$ values. Note that American crocodile Crocodylus acutus plots closer to the marine reptiles (marine iguana Amblyrhynchus cristatus and loggerhead turtle Caretta caretta) than either coastal or inland alligators Alligator mississippiensis 
atite, the expectation is the same. Estuaries in both western LA and FL have very similar DIC $\delta^{13} \mathrm{C}$ values, increasing as salinity increases (Sackett et al. 1997, Kaldy et al. 2005). The expected trend is observed and significant $\left(t_{32.8}=-7.3, \mathrm{p}<0.0001\right)$, clearly separating the inland populations from the coastal and marine crocodylian populations and species (Fig. 2). The high $\delta^{13} \mathrm{C}$ values observed in coastal alligators and crocodiles likely reflect consumption of marine resources. An alternative explanation, however, is that $\mathrm{C}_{4}$ vegetation could be influencing the aquatic food webs in which the alligators and/or crocodiles are feeding. $\mathrm{C}_{4}$ grasses do occur in FL, but in coastal swamps and marshes, freshwater $\mathrm{C}_{3}$ macrophytes and algae form the base of the food web (Williams \& Trexler 2006, Troxler \& Richards 2009). We are aware of no evidence suggesting that terrestrial $\mathrm{C}_{4}$ plants increase in riparian and swamp communities near the ocean. Thus, we contend that the conspicuously higher $\delta^{13} \mathrm{C}$ values of crocodylians near the coast are due to marine carbon influence in brackish water and estuaries.

Sr isotope ratios provide 1 test of the hypothesis that marine resources, rather than $\mathrm{C}_{4}$ resources, are the source of high $\delta^{13} \mathrm{C}$ values in coastal crocodylians. Crocodylians ingest bone, which is much more concentrated in Sr than water (FL river freshwater $\approx 0.5 \mathrm{ppm} \mathrm{Sr}$, seawater $\approx 7 \mathrm{ppm} \mathrm{Sr}$, Bryant \& Mueller 1995; bone $\approx 200$ ppm Sr, Blincoe et al. 1973). Therefore, food will control the ${ }^{87} \mathrm{Sr} /{ }^{86} \mathrm{Sr}$ ratios of bones and teeth, as well as their $\delta^{13} \mathrm{C}$ values. If high $\delta^{13} \mathrm{C}$ values reflect use of marine resources, we would expect ${ }^{87} \mathrm{Sr} /{ }^{86} \mathrm{Sr}$ ratios to approach the value of modern seawater (0.7092) as $\delta^{13} \mathrm{C}$ values rise. Although in restricted basins the ${ }^{87} \mathrm{Sr} /{ }^{86} \mathrm{Sr}$ ratio can be altered by local river influence, the ${ }^{87} \mathrm{Sr} /{ }^{86} \mathrm{Sr}$ ratio of water in
Biscayne Bay (a popular nesting site for Crocodylus acutus) is indistinguishable from seawater (Stalker et al. 2009). Although we are aware of no coastline measurements of seawater from RWR, measurements near the Mississippi Delta in eastern LA (where river influence should be much higher than at RWR) indicate that by the time water reaches $35 \mathrm{psu}$, the ${ }^{87} \mathrm{Sr} /{ }^{86} \mathrm{Sr}$ ratio is the same as seawater (Xu \& Marcantonio 2007).

${ }^{87} \mathrm{Sr} /{ }^{86} \mathrm{Sr}$ ratios of FL crocodylians (Table 2) are consistent with those of terrestrial mammals collected across FL by Hoppe et al. (1999). Among all coastal crocodylians (filled symbols in Fig. 4A), there is a trend towards higher $\delta^{13} \mathrm{C}$ values as ${ }^{87} \mathrm{Sr} /{ }^{86} \mathrm{Sr}$ ratios approach $0.7092\left(\mathrm{R}^{2}=0.6\right)$. We contend that this correlation is evidence that high $\delta^{13} \mathrm{C}$ values for coastal crocodylians (both alligators and crocodiles) are due to the influence of marine carbon. The inland alligators, which have no access to marine resources unless they are migratory (open symbols in Fig. 4A), do not show this pattern. The inland alligators from southern FL have ${ }^{87} \mathrm{Sr} /{ }^{86} \mathrm{Sr}$ ratios in the same range as coastal crocodylians. The bedrock in this region is Late Quaternary limestone, with ${ }^{87} \mathrm{Sr} /{ }^{86} \mathrm{Sr}$ ratios essentially identical to modern seawater (Weedman et al. 1999). Thus, alligators with entirely terrestrial/ freshwater diets that are supplied with Sr only from bedrock soils (e.g. sink hole or standing water wetland versus a river draining a large area with disparate ${ }^{87} \mathrm{Sr} /{ }^{86} \mathrm{Sr}$ ratios) could have ratios similar to modern seawater (0.7092). We observed ${ }^{87} \mathrm{Sr} /{ }^{86} \mathrm{Sr}$ ratios higher than modern seawater in 2 southern FL alligators (open circle and filled triangle, Fig. 4A) as well as the 3 crocodiles from southern FL (filled diamonds, Fig. 4A). The implication is that soil is being labeled with a $\mathrm{Sr}$ source other than seawater or

Table 2. Alligator mississippiensis and Crocodylus acutus. Sr, C, and O isotope data from tooth bioapatite and locality information for individual alligators and crocodiles. FL: Florida; LA: Louisiana; RWR: Rockefeller Wildlife Refuge

\begin{tabular}{|lccrrrl}
\hline Species & ID no. & Ecology & ${ }^{87} \mathrm{Sr} /{ }^{86} \mathrm{Sr}$ & $\delta^{13} \mathrm{C}$ & $\delta^{18} \mathrm{O}$ & Location \\
\hline A. mississippiensis & UF10941 & Coastal & 0.7093 & -13.6 & -0.4 & FL, Collier Co. \\
A. mississippiensis & RWR10-O & Coastal & 0.7091 & -9.9 & 1.0 & LA, RWR \\
A. mississippiensis & RWR 30 & Coastal & 0.7095 & -12.9 & -1.0 & LA, RWR \\
A. mississippiensis & RWR 17 & Coastal & 0.7092 & -9.9 & 1.0 & LA, RWR \\
C. acutus & UF56671-D & Coastal & 0.7094 & -12.9 & -1.1 & FL, Collier Co. \\
C. acutus & UF54201-A & Coastal & 0.7092 & -8.0 & 0.4 & FL, Monroe Co. \\
C. acutus & UF56580-A & Coastal & 0.7095 & -14.5 & -0.4 & FL, Monroe Co. \\
A. mississippiensis & UF87886-B & Inland & 0.7093 & -17.0 & 1.2 & FL, Broward Co. \\
A. mississippiensis & UF42548-B & Inland & 0.7085 & -13.0 & -3.5 & FL, Clay Co. \\
A. mississippiensis & UW G3 & Inland & 0.7091 & -15.4 & 2.4 & FL, Everglades \\
A. mississippiensis & UW G2 & Inland & 0.7091 & -16.3 & 2.5 & FL, Everglades \\
A. mississippiensis & UF42872-A & Inland & 0.7101 & -11.6 & -4.5 & FL, Polk Co. \\
\hline
\end{tabular}


- C. acutus (southern FL)

- Coastal A. mississippiensis (LA)

Coastal A. mississippiensis (southern FL)
Inland A. mississippiensis (northern and central FL)

Inland A. mississippiensis (southern FL)
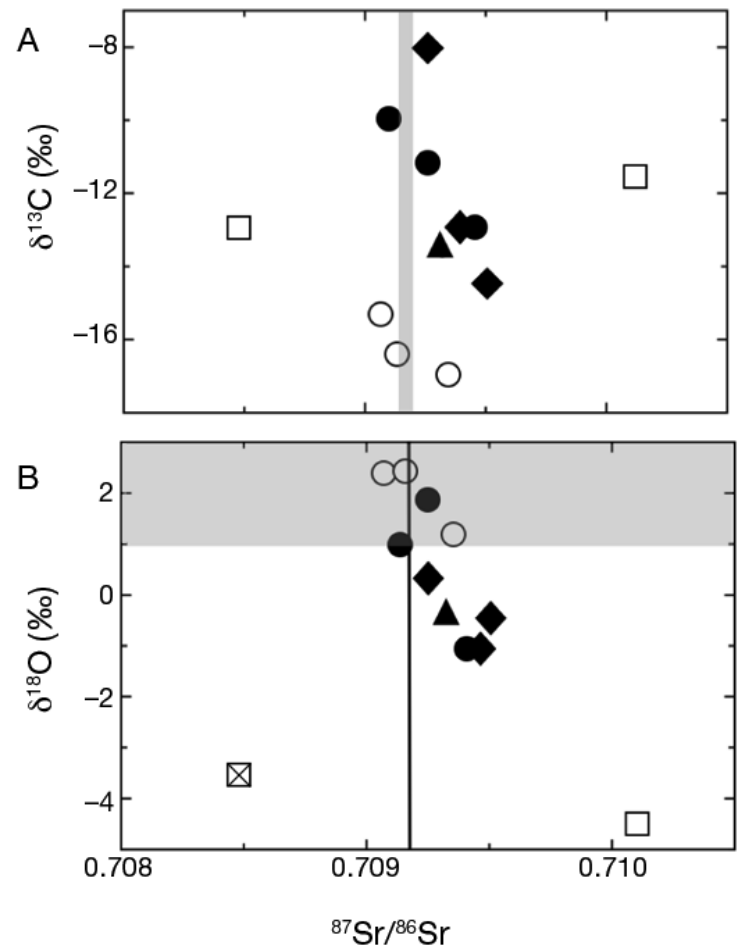

Fig. 4. Alligator mississippiensis and Crocodylus acutus. ${ }^{87} \mathrm{Sr} /{ }^{86} \mathrm{Sr}$ ratios versus (A) $\delta^{13} \mathrm{C}$ and (B) $\delta^{18} \mathrm{O}$ values for several crocodylians. Filled symbols are coastal individuals and open symbols are inland individuals. Vertical line at ${ }^{87} \mathrm{Sr} /{ }^{86} \mathrm{Sr}$ ratio of 0.7092 is ratio of modern seawater. Horizontal shading in (B) indicates $\delta^{18} \mathrm{O}$ values likely affected by evaporation. In (A), for all coastal crocodylians there is a trend towards higher $\delta^{13} \mathrm{C}$ values as ${ }^{87} \mathrm{Sr} /{ }^{86} \mathrm{Sr}$ ratios approach $0.7092\left(R^{2}=0.6\right)$. In $(B)$, all crocodylians (with the exception of 1 outlier $\otimes$ from northern Florida) show a trend towards higher $\delta^{18} \mathrm{O}$ as ${ }^{87} \mathrm{Sr} /{ }^{86} \mathrm{Sr}$ ratios approach $0.7092\left(\mathrm{R}^{2}=0.87\right)$

bedrock. African dust does reach southern FL in quantities that could label soil with ${ }^{87} \mathrm{Sr} /{ }^{86} \mathrm{Sr}$ ratios that average around 0.7179 , substantially higher than seawater (Muhs et al. 2007, Pett-Ridge et al. 2009). This provides a plausible mechanism for having high ${ }^{87} \mathrm{Sr} /{ }^{86} \mathrm{Sr}$ ratios in southern FL soils and therefore southern FL alligators and crocodiles with ${ }^{87} \mathrm{Sr} /{ }^{86} \mathrm{Sr}$ ratios higher than seawater.

Because it is likely that crocodylian $\mathrm{Sr}$ is largely supplied by food, not water, we were surprised by the tight correlation between $\delta^{18} \mathrm{O}$ values (a proxy for drinking water) and ${ }^{87} \mathrm{Sr} /{ }^{86} \mathrm{Sr}$ ratios $\left(\mathrm{R}^{2}=0.87\right)$ when eliminating the 1 outlier from northern FL. While

there are relationships between salinity and both $\delta^{18} \mathrm{O}$ values and ${ }^{87} \mathrm{Sr} /{ }^{86} \mathrm{Sr}$ ratios, the tight linear correlation in Fig. 4B is puzzling. The relationship between salinity and $\delta^{18} \mathrm{O}$ value in a 2 end-member mixing scenario is a straight line, because the concentration of oxygen does not change between seawater and fresh water. The relationship between ${ }^{87} \mathrm{Sr} /{ }^{86} \mathrm{Sr}$ and salinity, on the other hand, is typically exponential or logarithmic because $\mathrm{Sr}$ is an order of magnitude more concentrated in seawater than in fresh water (Bryant \& Mueller 1995). Therefore, if the ${ }^{87} \mathrm{Sr} /{ }^{86} \mathrm{Sr}$ ratio of crocodylian teeth is being primarily controlled by drinking water, we would expect to see an exponential relationship between $\delta^{18} \mathrm{O}$ and ${ }^{87} \mathrm{Sr} /{ }^{86} \mathrm{Sr}$, but instead we see a linear trend. Because $\mathrm{Sr}$ concentration in bone does not change appreciably between marine and terrestrial environments (Burton \& Price 1999), the observed linear trend supports our inference that the ${ }^{87} \mathrm{Sr} /{ }^{86} \mathrm{Sr}$ ratio is controlled by food rather than water Sr.

We offer 2 scenarios to explain the linear correlation of $\delta^{18} \mathrm{O}$ and ${ }^{87} \mathrm{Sr} /{ }^{86} \mathrm{Sr}$. First, for coastal crocodylians (filled symbols in Fig. 4B) the influences of marine food and marine oxygen - either from food and water in the case of Crocodylus acutus or from food in the case of Alligator mississippiensis-are providing information about the same sources (marine versus terrestrial/ freshwater environment) and some correlation among all 3 tracers $\left(\delta^{18} \mathrm{O}, \delta^{13} \mathrm{C}\right.$, and ${ }^{87} \mathrm{Sr} /{ }^{86} \mathrm{Sr}$ ) is to be expected. Second, for the inland alligators (open symbols in Fig. 4B), excepting the outlier from northern FL, the linear trend is probably a combination of latitudinal variation in $\delta^{18} \mathrm{O}$ value of surface waters and southern FL geology. A transect of bedrock from central to southern FL moves from Paleogene sedimentary rocks to Pleistocene limestone, and the ${ }^{87} \mathrm{Sr} /{ }^{86} \mathrm{Sr}$ ratio shifts from $\sim 0.7095$ to $\sim 0.7092$ (Scott 1992, Hoppe et al. 1999). Along the same transect, $\delta^{18} \mathrm{O}$ values of surface waters increase because of a change in the $\delta^{18} \mathrm{O}$ value of precipitation and increased evaporation from north to south (Meyers et al. 1993, Gat 1996, Kendall \& Coplen 2001). Note that for the $\delta^{18} \mathrm{O}$ values higher than $\sim 1 \%$ (grey area in Fig. 4B), it is unlikely that the source of water is marine, but more likely that evaporation has increased the freshwater $\delta^{18} \mathrm{O}$ value (Meyers et al. 1993).

Results from the Sr isotope analyses generally corroborate the idea that animals with higher $\delta^{13} \mathrm{C}$ are influenced by marine carbon. However, because southern FL bedrock and ocean water have essentially the same ${ }^{87} \mathrm{Sr} /{ }^{86} \mathrm{Sr}$ ratio and because our Crocodylus acutus data come from southern FL, we chose 
to omit the $\mathrm{Sr}$ isotope system when estimating the contribution of marine resources to $C$. acutus (Table 3).

\section{Comparing different species and locations}

To estimate the amount of marine resources used in Crocodylus acutus (see 'Marine resource use in crocodylians' below), it is necessary to compare different species from different locations. In estimating the source of the water ingested by C. acutus, we will compare the variability in $\delta^{18} \mathrm{O}$ values from the C. acutus population in southern FL $(\mathrm{SD}=0.8)$ to the coastal population of obligate freshwater-drinking Alligator mississippiensis-primarily from RWR in LA ( $\mathrm{SD}=1.6)$ - and to the population of marine iguanas $(\mathrm{SD}=0.6)$. Loggerhead turtles were excluded as a marine end-member for $\delta^{18} \mathrm{O}$ because the calculation involves variability, and we were concerned about biases due to differences in time averaging for teeth (short) in crocodylians and iguanas versus bone (long) in loggerhead turtles. However, addition of the loggerhead turtle data does not change the result of the analysis, as the loggerhead population has the same SD as the marine iguana population (see 'Materials and methods'). We chose to compare C. acutus to a population of coastal alligators (for which we have no population-level data in FL). Alternatively, C. acutus could be compared to an obligate freshwaterdrinking reptile from nearby. If one chooses to compare $C$. acutus to southern FL inland alligators (which are geographically closer, but in our opinion, less ecologically similar), the result would shift towards $C$. acutus ingesting more marine water due to the larger SD of the southern FL alligators $(\mathrm{SD}=2.2$ ).
When choosing our terrestrial end-member for the food $\left(\delta^{13} \mathrm{C}\right)$ mixing analysis, we cannot assume that coastal alligators are feeding exclusively in a terrestrial food web. Alligators have been sighted in the ocean, on beaches, and frequently in brackish water (Elsey 2005). Because they are not capable of drinking saline water, it is likely they are foraging on marine food in these areas. Therefore, we used the inland Alligator mississippiensis as our terrestrial carbon end-member $\left(\delta^{13} \mathrm{C}=-15.8 \%\right.$ ).

Choosing the marine end-member for the food mixing analysis is more nuanced. We are reluctant to compare carnivorous crocodylians to herbivorous marine iguanas because there is potential for gut fermentation of plant matter by the iguanas to raise the $\delta^{13} \mathrm{C}$ value of bioapatite (see 'Marine reptiles'). Therefore, we chose to compare the crocodylians to carnivorous marine turtles. This comparison is further complicated because baseline $\delta^{13} \mathrm{C}$ values can vary by location for marine food webs. To estimate baseline $\delta^{13} \mathrm{C}$ values across locations, we used sediment organic matter from the areas of interest as a proxy for the changes in relative baseline $\delta^{13} \mathrm{C}$ values of those food webs.

Organic sediment from the coast of southern FL has an average $\delta^{13} \mathrm{C}$ value of $-18.5 \%$ (Macko et al. 1984). Organic sediment off the Pacific coast of Baja has an average $\delta^{13} \mathrm{C}$ value of $-20.0 \%$ (Voss et al. 2001). Therefore we adjusted the Pacific loggerhead turtles by $+2.5 \%$ o when comparing them to Crocodylus acutus from southern FL. Our sample of loggerhead turtles is broad ( $\mathrm{n}=31)$, but relatively distant from southern FL, and problems can arise when comparing even the same species from different ocean basins (Wallace \& Saba 2009). To mediate the effects of 2 ocean basins and distance in general, we

Table 3. Crocodylus acutus. Values and results for the mixing equation $C=M(X)+T(1-X)$ (Eq. 2, see 'Results and Discussion') to estimate the amount of marine resources consumed by C. acutus in southern Florida (FL). Note that for oxygen, the mixing equation uses variability (1 SD) for each population's $\delta^{18} \mathrm{O}$ values, and for carbon, the equation uses mean $\delta^{13} \mathrm{C}$ values $(\%$ relative to V-PDB). Error (1 SD) on $\delta^{13} \mathrm{C}$ marine contribution estimate derived from IsoError (Phillips \& Gregg 2001) using inputs from Table 1. LA: Louisiana

\begin{tabular}{|ccccccc}
\hline & $\begin{array}{c}\text { Marine end- } \\
\text { member }\end{array}$ & $\begin{array}{c}\text { Marine } \\
\text { isotope } \\
\text { value }(M)\end{array}$ & $\begin{array}{c}\text { Terrestrial } \\
\text { end-member }\end{array}$ & $\begin{array}{c}\text { Terrestrial } \\
\text { isotope } \\
\text { value }(T)\end{array}$ & $\begin{array}{c}\text { C. acutus } \\
\text { isotope } \\
\text { value }\end{array}$ & $\begin{array}{c}\text { \% Marine } \\
\text { contribution } \\
(X)\end{array}$ \\
\hline $\begin{array}{c}\delta^{18} \mathrm{O} \% \mathrm{SD} \\
(\text { water })\end{array}$ & Marine iguanas & 0.6 & Coastal LA and FL alligators & 1.6 & 0.8 & 80 \\
$\begin{array}{c}\delta^{13} \mathrm{C} \% \\
\text { mean } \\
(\text { food) }\end{array}$ & $\begin{array}{c}\text { Adjusted average of sea } \\
\text { turtles from this study } \\
\text { and Biasatti (2004). } \\
\text { See 'Results and discussion' }\end{array}$ & Inland alligators & -15.8 & -9.6 & $65 \pm 9$ \\
\hline
\end{tabular}


averaged our data set with $\delta^{13} \mathrm{C}$ carbonate values from leatherback turtles Dermochelys coriacea primarily collected in Guyana from Biasatti (2004) $\left(\delta^{13} \mathrm{C}=-9.6 \pm 2.2, \mathrm{n}=5\right)$. Organic sediments off the coast of Guyana average $-21.0 \%$ (Medina et al. 2005), and we adjusted the leatherback $\delta^{13} \mathrm{C}$ values accordingly $(+3.5 \%)$ for comparison with $C$. acutus from southern FL.

\section{Marine resource use in crocodylians}

We used simple 2 end-member linear mixing equations to estimate the percent of marine resource use by Crocodylus acutus. We assumed that the animals have only 2 inputs (marine and terrestrial) and then calculated the proportional contribution of the marine end-member $(X)$ to $C$. acutus isotope values. The equation takes the following form:

$$
C=M(X)+T(1-X)
$$

where $C$ is the isotopic value for $C$. acutus, $M$ is the isotopic value for the marine end-member, and $T$ is the isotopic value for the terrestrial end-member. Table 3 contains the end-members we selected as well as their isotopic values and the calculated percent of marine contribution to C. acutus.

Our approach to carbon isotope mixing is straightforward, and follows many prior studies (e.g. Phillips $\&$ Koch 2002). Our approach to oxygen isotope mixing, in contrast, is not standard and merits further comment. We did not use mean $\delta^{18} \mathrm{O}$ values in our mixing model because we suspected that inland alligators have variably ${ }^{18} \mathrm{O}$-enriched values due to latitudinal and evaporative effects. Instead we used the $\delta^{18} \mathrm{O} \mathrm{SD}$ as a proxy for ingestion of marine versus fresh water. While not an 'input' to an individual animal with a defined isotopic value, such as food carbon or water oxygen, variance at the population level is a characteristic that shows a clear and predictable difference between marine and terrestrial populations.

We estimated that the average Crocodylus acutus ingests $80 \%$ seawater (either via drinking or from food or metabolic water), based on the $\delta^{18} \mathrm{O}$ SD mixing model. Given that we calculated this number based upon the variance that the population exhibits in $\delta^{18} \mathrm{O}$ value, there is currently no way to estimate the error envelope surrounding our calculated value of seawater consumed. The estimate of $80 \%$ seawater consumption could manifest itself in a multitude of ways. The 2 extreme cases are (1) that the average C. acutus ingests seawater $80 \%$ of the time and freshwater $20 \%$ of the time, or (2) that C. acutus ingests water that is an 80/20 mix of seawater/freshwater $100 \%$ of the time. Obviously, a scenario between those 2 possibilities is most likely. If our results indicate direct ingestion of seawater, the value is high relative to published estimates for Crocodylidae. Though no prior study has attempted to measure the actual intake of salt water by $C$. acutus in the field, most researchers argue that while C. acutus are often present where salinities are high, they probably do not consume this water, but instead imbibe when they return to low-salinity water (Dunson 1982, Mazzotti \& Dunson 1984, 1989, Kushlan \& Mazzotti 1989, Jackson et al. 1996). However, most assumptions about low saltwater tolerance in Crocodylidae are derived from laboratory studies on small individuals or hatchlings (e.g. Dunson 1970, Evans \& Ellis 1977). In contrast, Dunson (1982) found that adult $C$. acutus could remain healthy for extended periods of time in water salinities as high as $26 \mathrm{psu}$ (74\% seawater), perhaps indicating a greater tolerance for ingestion of saltwater.

Alternatively, the bulk of the $\delta^{18} \mathrm{O}$ signal in Crocodylus acutus could be from water included within or derived from food. If the prey is marine, then ultimately that water is sourced from the ocean and will have a $\delta^{18} \mathrm{O}$ value close to $0 \%$. However, this water is potentially less salty than seawater. Many estuarine and marine crustaceans maintain high hemolymph concentrations of salinity ranging from $70 \%$ that of seawater to iso-osmotic with seawater (Mantel \& Farmer 1983). Marine 'fish' maintain blood salt concentrations from about 15 to $50 \%$ that of ocean water (Ditrich 2007). Although crocodylians may ultimately be finding some sources of water that are less than the $35 \mathrm{psu}$ of seawater in the ocean (potentially through prey body-water), this study is primarily concerned with the ability of crocodylians to be ecologically divorced from freshwater ecosystems. Thus, our result of $80 \%$ marine water consumption should not necessarily be viewed as commentary on the saltexcreting physiological abilities of $C$. acutus, but rather as a percentage of time that $C$. acutus could be acting as a functional marine reptile living independently of a freshwater ecosystem.

Our estimate for the percentage of marine carbon derived through diet for the average Crocodylus acutus is $65 \pm 9 \%$ (error on the mixing model estimate was calculated using IsoError; Phillips \& Gregg 2001). Comparisons of this value with more traditional studies of $C$. acutus diet (e.g. gut content analysis) are problematic. Many gut content studies report data as a percentage of the number of preda- 
tor stomachs in which a particular prey item was found. Unfortunately, this is the case for both stomach content studies done for $C$. acutus at coastal sites (Seijas 1988, Thorbjarnarson 1988b). This data set does not control for the fact that large prey items, even if only found in a small percentage of stomachs, could be more important dietary items than small ubiquitous prey items like insects. Nonetheless, our estimate of $65 \%$ marine diet is plausible in the context of these studies. Thorbjarnarson (1988b) reported $71 \%$ of crocodile stomachs containing crustaceans, which were predominately the marine crab Uca bergersii, whereas the vast majority of other prey comprised smaller insects. Seijas's (1988) data are more difficult to compare. In that study, C. acutus was shown to be highly reliant on crabs and fish, especially in larger animals, but no information was given regarding the freshwater or marine status of the prey for the coastal sites analyzed.

The estimate of a $65 \%$ marine diet based on carbon isotope mixing is lower than our estimate for marine influence on ingested water $(80 \%)$. The apparent implication is that Crocodylus acutus drinks in saltier water than it feeds, which would be curious behavior. But the reality is that terrigenous plumes can extend far from the mouths of rivers in FL (e.g. Jolliff et al. 2003) carrying terrestrial carbon with them, and in Florida Bay (a nesting area for the C. acutus population), sediments can contain as much as $60 \%$ terrestrial (rather than marine) organic matter $(\mathrm{Xu}$ et al. 2006), which can provide an allocthonous source of carbon to the marine food web. Therefore, C. acutus could easily receive both its food and water from 1 geographic area without receiving equal marine inputs from each. Note that this dietary paradox of a high percentage of terrestrial dietary items is seemingly supported by the crocodile $\mathrm{Sr}$ isotope results, which are higher than marine values (Table 2, Fig. 4). This is most likely due to our small sample size coupled with individual variation. The 3 crocodiles sampled for Sr analysis had the lowest $\delta^{18} \mathrm{O}$ values of the crocodiles analyzed in this study, and 2 of the 3 (UF 56580 and UF 56671D) had lower than average $\delta^{13} \mathrm{C}$ values (Table A1 in Appendix 1) and are therefore probably habitually more terrestrial than average.

Our results indicate that Crocodylus acutus and coastal Alligator mississippiensis are eating similar amounts of marine food, $65 \pm 9 \%$ and $77 \pm 20 \%$, respectively. When calculating the A. mississippiensis mixture, the sea turtles are adjusted to the marine sediment in the northwest Gulf of Mexico: $\delta^{13} \mathrm{C}=$ -20.6 (Macko et al. 1984; see 'Comparing different species and locations'). This adjustment results in a higher estimate of marine food than that of $C$. acutus (though within error) despite a lower mean $\delta^{13} \mathrm{C}$ value. Although several gut content studies have been done on coastal LA alligators (e.g. McNease \& Joanen 1977, Wolfe et al. 1987, Elsey et al. 1992), comparisons of our isotopic data to the gut content analyses are not straightforward due to gut contents typically being binned by large phylogenetic rather than ecological groups (e.g. 'fish' may include freshwater and marine species). Gut content studies are wide ranging with respect to preferred prey items in their reported results. Elsey et al. (1992) and some surveys of McNease \& Joanen (1977) would fall within our estimate's error envelope of percent reliance on marine prey $(\sim 65-70 \%$ and $\sim 60 \%$, respectively); other surveys from McNease \& Joanen (1977) and Wolfe et al. (1987) would indicate much heavier reliance on aquatic mammals (specifically nutria) than marine fish or crustaceans.

In contrast to the hypothesis of Dunson \& Mazzotti (1989), our data suggest that levels of incidental ingestion of seawater during feeding must be quite low, otherwise we would expect a comparable degree of variance in $\delta^{18} \mathrm{O}$ values between crocodiles and alligators from the same region. Likewise, despite the fact that these animals ingest prey bodywater that must have a marine $\delta^{18} \mathrm{O}$ value (which presumably makes the mean tooth carbonate $\delta^{18} \mathrm{O}$ values more similar between the 2 populations), the difference in variance between coastal alligators and crocodiles suggests that this prey body-water makes only a minor contribution to the oxygen and water mass balance of these animals. Our data cannot exclude the possibility that in an estuarine environment, marine organisms could make their way into waters of varying salinity, resulting in Alligator mississippiensis consuming foods similar in $\delta^{13} \mathrm{C}$ value to Crocodylus acutus but in lower salinity waters. In any case, alligator populations in coastal settings are using fresh water to an extent that coastal populations of $C$. acutus are not-even when the amounts of marine food being consumed are comparable.

The similar amounts of marine food in the diets of the 2 species imply that where their ranges overlap, there could be significant competition for resources and perhaps space. This possibility has largely been unexplored, probably because the area where these 2 animals' ranges overlap is small compared to the full range of each species. However, the range of Crocodylus acutus in FL appears to be thermally constrained (Kushlan \& Mazzotti 1989). Yet if rapid climate change in the future results in warmer winters, C. acutus population ranges in FL could expand. If 
this happens, we have little knowledge of how C. acutus and Alligator mississippiensis would interact competitively.

\section{CONCLUSIONS}

Our results support the conclusion of the study of Clementz \& Koch (2001) on mammals, which suggested that mean $\delta^{18} \mathrm{O}$ values offer a weak monitor of marine versus terrestrial water consumption. However, as in Clementz \& Koch (2001), the standard deviations around the mean $\delta^{18} \mathrm{O}$ values are informative. In reptiles, populations of animals consuming seawater (directly or via food) have lower variance than animals that consume fresh water.

We estimated that $80 \%$ of the water ingested by the average Crocodylus acutus in southern FL is marine water, although this estimate may include water derived from marine prey, which can be of lower salinity than seawater. The average southern FL C. acutus contains $65 \pm 9 \%$ prey items originating in the marine environment. Estimates of marine food use by $C$. acutus and Alligator mississippiensis are comparable. We hypothesize that significant competition for resources may occur in areas where these species overlap. Although that area is currently small, climate change could expand the range of C. acutus in FL, and further study of competitive interactions between the 2 American crocodylians is warranted. Our estimates of marine resource use by C. acutus in southern FL is high compared to prior hypotheses, but $C$. acutus is observed in waters that are 28 psu or higher, and laboratory data confirm that adult $C$. acutus can remain healthy in waters of approximately this salinity. According to our data, it appears that extensive behavioral osmoregulation by frequently returning to fresh water to drink or avoiding drinking water containing more than $10 \mathrm{psu}$ is not required of $C$. acutus. For much of the time, C. acutus may be capable of being ecologically isolated from freshwater ecosystems.

Acknowledgements. H. Schwartz, J. Zachos, and 4 anonymous reviewers made suggestions to better this manuscript, and it is much improved thanks to their efforts. We thank R, Elsey at Rockefeller Wildlife Refuge (RWR) in Louisiana for supplying samples from RWR. We thank the University of Florida (UF) curators, M. Nickerson, K. Krysko, and especially F.W. King, for access and permission to sample the UF crocodylian collection. J. Vendum at the California Academy of Sciences provided access and samples of marine iguanas. Although sampling logistics never worked out, M. Slaughter at J.D. Murphree WMA in Port Author, Texas, was very helpful in trying to supply samples for this study. Sup- port for this research was supplied by CDELSI and by NSF Grant EAR-0819943 to P.L.K.

\section{LITERATURE CITED}

Amiot R, Lécuyer C, Escarguel G, Billon-Bruyant JP and others (2007) Oxygen isotope fractionation between crocodilian phosphate and water. Palaeogeogr Palaeoclimatol Palaeoecol 243:412-420

Amiot R, Buffetaut E, Lécuyer C, Wang X and others (2010) Oxygen isotope evidence for semi-aquatic habits among spinosaurid theropods. Geology 38:139-142

Bentley RA (2006) Strontium isotopes from the Earth to the archaeological skeleton: a review. J Archaeol Method Theory 13:135-187

Biasatti DM (2004) Stable carbon isotopic profiles of sea turtle humeri: implications for ecology and physiology. Palaeogeogr Palaeoclimatol Palaeoecol 206:203-216

- Billon-Bruyat JP, Lecuyer C, Martineau F, Mazin JM (2005) Oxygen isotope compositions of Late Jurassic vertebrate remains from lithographic limestones of western Europe: implications for the ecology of fish, turtles, and crocodilians. Palaeogeogr Palaeoclimatol Palaeoecol 216: 359-375

Blincoe C, Lesperance AL, Bohman VR (1973) Bone magnesium, calcium and strontium concentrations in range cattle. J Anim Sci 36:971-975

Bolnick DI, Svanback R, Fordyce JA, Yang JM, Davis JM, Hulsey CD, Forister ML (2003) The ecology of individuals: incidence and implications of individual specialization. Am Nat 161:1-28

> Bowen BW, Abreu-Grobois FA, Balazs GH, Kamezaki N, Limpus CJ, Ferl RJ (1995) Trans-Pacific migration of the loggerhead turtle (Caretta caretta) demonstrated with mitochondrial DNA markers. Proc Natl Acad Sci USA 92: 3731-3734

Brien ML, Read MA, McCallum HI, Grigg GC (2008) Home range and movements of radio-tracked estuarine crocodiles (Crocodylus porosus) within a non-tidal waterhole. Wildl Res 35:140-149

Brochu CA (2000) Congruence between physiology, phylogenetics and the fossil record on crocodylian historical biogeography. In: Grigg GC, Seebacher F, Franklin CE (eds) Crocodilian biology and evolution. Surrey Beatty \& Sons, Chipping Norton, p 9-28

> Brochu CA (2003) Phylogenetic approaches toward crocodylian history. Annu Rev Earth Planet Sci 31:357-397

Bryant JD, Mueller P (1995) Influence of freshwater flux on ${ }^{87} \mathrm{Sr} /{ }^{86} \mathrm{Sr}$ chronostratigraphy in marginal marine environments and dating of vertebrate and invertebrate faunas. J Paleontol 69:1-6

> Burke WH, Denison RE, Hetherington EA, Koepnick RB, Nelson BK, Otto JB (1982) Variation of seawater ${ }^{87} \mathrm{Sr} /{ }^{86} \mathrm{Sr}$ throughout Phanerozoic time. Geology 10:516-519

> Burton JH, Price TD (1999) Evaluation of bone strontium as a measure of seafood consumption. Int J Osteoarchaeol 9:233-236

Butcher MT, Espinoza NR, Cirilo SR, Blob RW (2008) In vivo strains in the femur of river cooter turtles (Pseudemys concinna) during terrestrial locomotion: tests of forceplatform models of loading mechanics. J Exp Biol 211: 2397-2407

Capo RC, Stewart BW, Chadwick OA (1998) Strontium isotopes as tracers of ecosystem processes: theory and 
methods. Geoderma 82:197-225

Carpenter CC (1966) The marine iguana of the Galápagos Islands, its behavior and ecology. Proc Calif Acad Sci 34: 329-376

Cherkiss MS, Romañach SS, Mazzotti FJ (2011) The American crocodile in Biscayne Bay, Florida. Estuaries Coasts 34:529-535

Clementz MT, Koch PL (2001) Differentiating aquatic mammal habitat and foraging ecology with stable isotopes in tooth enamel. Oecologia 129:461-472

Clementz MT, Hoppe KA, Koch PL (2003) A paleoecological paradox: the habitat and dietary preferences of the extinct tethythere Desmostylus, inferred from stable isotope analysis. Paleobiology 29:506-519

> Clementz MT, Goswami A, Gingerich PD, Koch PL (2006) Isotopic records from early whales and sea cows: contrasting patterns of ecological transition. J Vertebr Paleontol 26:355-370

Clementz MT, Fox-Dobbs K, Wheatley PV, Koch PL, Doak DF (2009) Revisiting old bones: coupled carbon isotope analysis of bioapatite and collagen as an ecological and palaeoecological tool. Geol J 44:605-620

De Ricqlés AJ (1976) On bone histology of fossil and living reptiles, with comments on its functional and evolutionary significance. In: Bellairs ADA, Cox CB (eds) Morphology and biology of reptiles, Vol 3. Academic Press, London, p 123-149

> Ditrich H (2007) The origin of vertebrates: a hypothesis based on kidney development. Zool J Linn Soc 150: 435-441

Doi H (2009) Spatial patterns of autochthonous and allochthonous resources in aquatic food webs. Popul Ecol 51: 57-64

Dunson WA (1970) Some aspects of electrolyte and water balance in three estuarine reptiles, the diamondback terrapin, American and 'salt water' crocodiles. Comp Biochem Physiol 32:161-174

$>$ Dunson WA (1982) Salinity relations of crocodiles in Florida Bay. Copeia 1982:374-385

Dunson WA, Mazzotti FJ (1989) Salinity as a limiting factor in the distribution of reptiles in Florida bay: a theory for the estuarine origin of marine snakes and turtles. Bull Mar Sci 44:229-244

Edmund AG (1962) Sequence and rate of tooth replacement in the crocodile. R Ont Mus Life Sci Contrib 56:1-42

> Elsey RM (2005) Unusual offshore occurrence of an American alligator. Southeast Nat 4:533-536

Elsey RM, McNease L, Joanen T, Kinler N (1992) Food habits of native wild and farm-released juvenile alligators. Proc Annu Conf Southeast Assoc Game Fish Comm 46:57-66

Evans DH, Ellis TM (1977) Sodium balance in the hatchling American crocodile, Crocodylus acutus. Comp Biochem Physiol A Physiol 58:159-162

Farquhar GD, Ehleringer JR, Hubick KT (1989) Carbon isotope discrimination and photosynthesis. Annu Rev Plant Physiol Plant Mol Biol 40:503-537

Frick MG, Williams KL, Bolten AB, Bjorndal KA, Martins HR (2009) Foraging ecology of the oceanic-stage loggerhead turtles Caretta caretta. Endang Species Res 9:91-97

Friedman I, O'Neil JR (1977) Compilation of stable isotope fractionation factors of geochemical interest. In: Fleischer M (ed) Data of geochemistry. Prof Pap 440-kk. US Geological Survey, Reston, VA

Fry B, Sherr EB (1984) $\delta^{13} \mathrm{C}$ measurements as indicators of carbon flow in marine and freshwater ecosytems. Contrib Mar Sci 27:15-47

Gat JR (1996) Oxygen and hydrogen isotopes in the hydrologic cycle. Annu Rev Earth Planet Sci 24:225-262

Godley BJ, Thompson DR, Waldron S, Furness RW (1998) The trophic status of marine turtles as determined by stable isotope analysis. Mar Ecol Prog Ser 166:277-284

Gremillion P, Wanielista M (2000) Effects of evaporative enrichment on the stable isotope hydrology of a central Florida (USA) river. Hydrol Process 14:1465-1484

Grigg GC, Beard LA, Moulton T, Queirol Melo MT, Taplin LE (1998) Osmoregulation by the broad-snouted caiman, Caiman latirostris, in estuarine habitat in southern Brazil. J Comp Physiol B Biochem Syst Environ Physiol 168: 445-452

Hedges REM (2003) On bone collagen — apatite-carbonate isotopic relationships. Int J Osteoarchaeol 13:66-79

> Hoppe KA, Koch PL, Carlson RW, Webb SD (1999) Tracking mammoths and mastodons: reconstruction of migratory behavior using strontium isotope ratios. Geology 27: 439-442

> Jackson K, Butler DG, Brooks DR (1996) Habitat and phylogeny influence salinity discrimination in crocodilians: implications for osmoregulatory physiology and historical biogeography. Biol J Linn Soc Lond 58:371-383

Joanen T, McNease L (1989) Ecology and physiology of nesting and early development of the American alligator. Am Zool 29:987-998

Jolliff J, Walsh JJ, He R, Weisberg R and others (2003) Dispersal of the Suwannee River plume over the West Florida shelf: simulation and observation of the optical and biochemical consequences of a flushing event. Geophys Res Lett 30:1709 doi:10.1029/2003GL016964

Kaldy JE, Cifuentes LA, Brock D (2005) Using stable isotope analyses to asses carbon dynamics in a shallow subtropical estuary. Estuaries 28:86-95

> Kay WR (2004) Movements and home ranges of radiotracked Crocodylus porosus in the Cambridge Gulf region of Western Australia. Wildl Res 31:495-508

Kendall C, Coplen TB (2001) Distribution of oxygen-18 and deuterium in river waters across the United States. Hydrol Process 15:1363-1393

- Kennedy BP, Klaue A, Blum JD, Folt CL, Nislow KH (2002) Reconstructing the lives of fish using $\mathrm{Sr}$ isotopes in otoliths. Can J Fish Aquat Sci 59:925-929

Koch PL (2007) Isotopic study of the biology of modern and fossil vertebrates. In: Michener R, Lajtha K (eds) Stable isotopes in ecology and environmental science. Blackwell Scientific Publication, Boston, MA, p 99-154

- Koch PL, Halliday AN, Walter LM, Stearley RF, Huston TJ, Smith GR (1992) Sr isotopic composition of hydroxyapatite from recent and fossil salmon: the record of lifetime migration and diagenesis. Earth Planet Sci Lett 108: $277-287$

- Koch PL, Tuross N, Fogel ML (1997) The effects of sample treatment and diagenesis on the isotopic integrity of carbonate in biogenic hydroxylapatite. J Archaeol Sci 24: $417-429$

Kocsis L, Vennemann TW, Fontignie D (2007) Migration of sharks into freshwater systems during the Miocene and implications for Alpine paleoelevation. Geology 35: 451-454

Kohn MJ (1996) Predicting animal $\delta^{18} \mathrm{O}$ : accounting for diet and physiological adaptation. Geochim Cosmochim Acta 60:4811-4829 
Kohn MJ, Cerling TE (2002) Stable isotope compositions of biological apatite. In: Kohn MJ, Rakovan J, Hughes JM (eds) Phosphates: geochemical, geobiological, and materials importance. Reviews in mineralogy and geochemistry, Vol 48. Mineralogical Society of America, Washington, DC, p 455-488

Kushlan JA, Mazzotti FJ (1989) Population biology of the American crocodile. J Herpetol 23:7-21

Laurén DJ (1985) The effect of chronic saline exposure on the electrolyte balance, nitrogen metabolism, and corticosterone titer in the American alligator, Alligator mississippiensis. Comp Biochem Physiol A Comp Physiol 81: 217-223

> LeGrande AN, Schmidt GA (2006) Global gridded data set of the oxygen isotopic composition in seawater. Geophys Res Lett 33:L12604 doi:10.1029/2006GL026011

> Leslie AJ, Spotila JR (2000) Osmoregulation of the Nile crocodile, Crocodylus niloticus, in Lake St. Lucia, Kwazulu/Natal, South Africa. Comp Biochem Physiol A Mol Integr Physiol 126:351-365

Macko S, Entzeroth L, Parker P (1984) Regional differences in nitrogen and carbon isotopes on the continental shelf of the Gulf of Mexico. Naturwissenschaften 71:374-375

Mantel LH, Farmer LL (1983) Osmotic and ionic regulation. In: Mantel LH (ed) The biology of Crustacea, Vol 5. Internal anatomy and physiological regulation. Academic Press, New York, NY, p 53-161

> Mazzotti FJ, Dunson WA (1984) Adaptations of Crocodylus acutus and Alligator for life in saline water. Comp Biochem Physiol A Physiol 79:641-646

Mazzotti FJ, Dunson WA (1989) Osmoregulation in crocodilians. Am Zool 29:903-920

McNease L, Joanen T (1977) Alligator diets in relation to marsh salinity. Proc Southeast Assoc Fish Wildl Agencies 31:36-40

Medina E, Francisco M, Sternberg L, Anderson WT (2005) Isotopic signatures of organic matter in sediments of the continental shelf facing the Orinoco Delta: Possible contribution of organic carbon from savannas. Estuar, Coastal Shelf Sci 63:527-536

> Meyers JB, Swart PK, Meyers JL (1993) Geochemical evidence for groundwater behavior in an unconfined aquifer, south Florida. J Hydrol 148:249-272

Muhs DR, Budahn JR, Prospero JM, Carey SN (2007) Geochemical evidence for African dust inputs to soils of western Atlantic islands: Barbados, the Bahamas, and Florida. J Geophys Res 112:F02009 doi:10.1029/2005JF000445

Newsome SD, Clementz MT, Koch PL (2010) Using stable isotope biogeochemistry to study marine mammal ecology. Mar Mamm Sci 26:509-572

> Page HM, Reed DC, Brzezinski MA, Melack JM, Dugan JE (2008) Assessing the importance of land and marine sources of organic matter to kelp forest food webs. Mar Ecol Prog Ser 360:47-62

> Pett-Ridge JC, Derry LA, Kurtz AC (2009) Sr isotopes as a tracer of weathering processes and dust inputs in a tropical granitoid watershed, Luquillo Mountains, Puerto Rico. Geochim Cosmochim Acta 73:25-43

Phillips DL, Gregg JW (2001) Uncertainty in source partitioning using stable isotopes. Oecologia 127:171-179

Phillips DL, Koch PL (2002) Incorporating concentration dependence in stable isotope mixing models. Oecologia 130:114-125

> Poyato-Ariza FJ, Talbot MR, Fregenal-Martínez MA, Meléndez N, Wenz S (1998) First isotopic and multidisci- plinary evidence for nonmarine coelacanths and pycnodontiform fishes: palaeoenvironmental implications. Palaeogeogr Palaeoclimatol Palaeoecol 144:65-84

Price TD, Gestsdóttir H (2006) The first settlers of Iceland: an isotopic approach to colonisation. Antiquity 80:130-144

Raven JA, Johnston AM, Kübler JE, Korb R and others (2002) Mechanistic interpretation of carbon isotope discrimination by marine macroalgae and seagrasses. Funct Plant Biol 29:355-378

> Read MA, Grigg GC, Irwin SR, Shanahan D, Franklin CE (2007) Satellite tracking reveals long distance coastal travel and homing by translocated estuarine crocodiles, Crocodylus porosus. PLoS One 2:e949

Rodda GH (1984) Movements of juvenile American crocodiles in Gatun Lake, Panama. Herpetologica 40:444-451

Roe LJ, Thewissen JGM, Quade J, Baipai S, Sahni A, Hussain ST (1998) Isotopic approaches to understanding the terrestrial to marine transition of the earliest cetaceans. In: Thewissen JGM (ed) The emergence of whales. Plenum Press, New York, NY, p 399-422

Sackett WM, Netratanawong T, Holmes ME (1997) Carbon13 variations in the dissolved inorganic carbon in estuarine waters. Geophys Res Lett 24:21-24

Schmitz B, Ingram SL, Dockery DT III, Aberg G (1997) Testing ${ }^{87} \mathrm{Sr} /{ }^{86} \mathrm{Sr}$ as a paleosalinity indicator on mixed marine, brackish-water and terrestrial vertebrate skeletal apatite in late Paleocene-early Eocene near-coastal sediments, Mississippi. Chem Geol 140:275-287

Scott TM (1992) A geological overview of Florida. Tallahassee, FL, Florida Geological Survey, (Open file report - Florida Geological Survey, 50)

Seijas AE (1988) Habitat use by the American crocodile and the spectacled caiman coexisting along the Venezuelan coastal region. Master's thesis, University of Florida, Gainesville, FL

Shoemaker VH, Nagy KA (1984) Osmoregulation in the Galápagos marine iguana, Amblyrhychus cristatus. Physiol Zool 57:291-300

Silva N, Vargas CA, Prego R (2011) Land-ocean distribution of allochthonous organic matter in surface sediments of the Chiloé and Aysén interior seas (Chilean Northern Patagonia). Cont Shelf Res 31:330-339

Smith KF, Sharp ZD, Brown JH (2002) Isotopic composition of carbon and oxygen in desert fauna: investigations into the effects of diet, physiology, and seasonality. J Arid Environ 52:419-430

Stalker JC, Price RM, Mcfarlane A (2009) Geochemical investigation of the surface water and groundwater in the immediate vicinity of Florida Power and Light Turkey Point cooling canals. Prepared for the South Florida Water Management District, (PO \# 4500035001). Retrieved from the Florida Department of Environmental Protection. Available at: http://publicfiles.dep.state.fl.us/ SEC/LewisLongmanWalkerTurkeyPoint/FPL\%2035.pdf

> Stoskopf MK, Barrick RE, Showers WJ (2001) Oxygen isotope variability in bones of wild caught and constant temperature reared sub-adult American alligators. J Therm Biol 26:183-191

Taplin LE (1988) Osmoregulation in crocodilians. Biol Rev Camb Philos Soc 63:333-377

Taplin LE, Grigg GC (1981) Salt glands in the tongue of the estuarine crocodile Crocodylus porosus. Science 212: 1045-1047

Taplin LE, Grigg GC, Beard LA (1985) Salt gland function in fresh water crocodiles: evidence for a marine phase in 
eusuchian evolution? In: Grigg G, Shine R, Ehmann H (eds) Biology of Australasian frogs and reptiles. Surrey Beatty \& Sons, Chipping Norton, p 403-410

Thewissen JGM, Roe LJ, O'Neil JR, Jussain ST, Sahni A, Bajpal S (1996) Evolution of cetacean osmoregulation. Nature 381:379-380

Thewissen JGM, Cooper LN, Clementz MT, Bajpai S, Tiwari $\mathrm{BN}$ (2007) Whales originated from aquatic artiodactyls in the Eocene epoch of India. Nature 450:1190-1194

Thorbjarnarson J (1988a) Ecology of the American crocodile, Crocodylus acutus. In: Crocodiles: their ecology, management and conservation. Crocodile Specialist Group Spec Publ. International Union for Conservation of Nature, Gland, p 228-258

Thorbjarnarson JB (1988b) The status and ecology of the American crocodile in Haiti. Bull Fla State Mus Biol Sci 33:1-86

Troxler TG, Richards JH (2009) $\delta^{13} \mathrm{C}, \delta^{15} \mathrm{~N}$, carbon, nitrogen and phosphorus as indicators of plant ecophysiology and organic matter pathways in Everglades deep slough, Florida, USA. Aquat Bot 91:157-164

> Vennemann TW, Hegner E, Cliff G, Venz GW (2001) Isotopic composition of recent shark teeth as a proxy for environmental conditions. Geochim Cosmochim Acta 65: 1583-1599

Voss M, Dippner JW, Montoya JP (2001) Nitrogen isotope patterns in the oxygen-deficient waters of the eastern tropical North Pacific Ocean. Deep-Sea Res I 48: 1905-1921

> Wallace BP, Saba VS (2009) Environmental and anthro- pogenic impacts on intra-specific variation in leatherback turtles: opportunities for targeted research and conservation. Endang Species Res 7:11-21

Wang Y, Cerling TE (1994) A model of fossil tooth and bone diagenesis-implications for paleodiet reconstruction from stable isotopes. Palaeogeogr Palaeoclimatol Palaeoecol 107:281-289

Weedman SD, Pailet FL, Edwards LE, Simmons KR and others (1999) Lithostratigraphy, geophysics, iostratigraphy, and strontium-isotope stratigraphy of the surficial aquifer system of eastern Collier County and northern Monroe County, Florida. Open-File Report 99-432. US Geological Survey, Tallahassee, FL

Wikelski M, Gall B, Trillmich F (1993) Ontogenetic changes in food intake and digestion rate of the herbivorous marine iguana (Amblyrhynchus cristatus, Bell). Oecologia 94:373-379

Williams AJ, Trexler JC (2006) A preliminary analysis of the correlation of food-web characteristics with hydrology and nutrient gradients in the southern Everglades. Hydrobiologia 569:493-504

Wolfe JL, Bradshaw DK, Chabreck RH (1987) Alligator feeding habits: new data and a review. Northeast Gulf Sci 9: 1-8

> Xu Y, Marcantonio F (2007) Strontium isotope variations in the lower Mississippi River and its estuarine mixing zone. Mar Chem 105:118-128

> Xu Y, Mead RN, Jaffe R (2006) A molecular marker-based assessment of sedimentary organic matter sources and distributions in Florida Bay. Hydrobiologia 569:179-192 


\section{Appendix 1}

Table A1. Alligator mississippiensis and Crocodylus acutus. Summary information for the crocodylians analyzed in this study. ID number followed by 'avg' indicates that multiple teeth were analyzed and averaged to achieve the reported $\delta^{13} \mathrm{C}$ and $\delta^{18} \mathrm{O}$ values. TL: total length; $\mathrm{n}$ : number of teeth analyzed per individual; na: not available; LA: Louisiana; N. (S.) FL: northern (southern) Florida. Some UF specimens have size or weight data associated with their entries in the Florida Museum of Natural History catalog

\begin{tabular}{|c|c|c|c|c|c|c|c|c|}
\hline ID & Size class & TL (m) & $\delta^{13} \mathrm{C} \pm \mathrm{SD}$ & $\delta^{18} \mathrm{O} \pm \mathrm{SD}$ & ${ }^{87} \mathrm{Sr} /{ }^{86} \mathrm{Sr}$ & Habitat & Location & $\mathrm{n}$ \\
\hline \multicolumn{9}{|c|}{ A. mississippiensis } \\
\hline RWR2 & Adult $^{\mathrm{a}}$ & na & $-8.2 \pm 0$ & $-0.9 \pm 0$ & - & Coastal & LA & 1 \\
\hline RWR3 & Adult $^{\mathrm{a}}$ & na & $-7.6 \pm 0$ & $-1.8 \pm 0$ & - & Coastal & LA & 1 \\
\hline RWR4 & Adult $^{\mathrm{a}}$ & na & $-7 \pm 0$ & $-2.3 \pm 0$ & - & Coastal & LA & 1 \\
\hline RWR5 & Adult $^{\mathrm{a}}$ & na & $-12 \pm 0$ & $-3.1 \pm 0$ & - & Coastal & LA & 1 \\
\hline RWR6 & Adult $^{a}$ & na & $-7.7 \pm 0$ & $-1.7 \pm 0$ & - & Coastal & LA & 1 \\
\hline RWR7 & Adult $^{\mathrm{a}}$ & na & $-12.2 \pm 0$ & $-3.8 \pm 0$ & - & Coastal & LA & 1 \\
\hline RWR8 & Adult $^{\mathrm{a}}$ & na & $-7.3 \pm 0$ & $-1.9 \pm 0$ & - & Coastal & LA & 1 \\
\hline RWR9 & Adult $^{\mathrm{a}}$ & na & $-7.6 \pm 0$ & $0.3 \pm 0$ & - & Coastal & LA & 1 \\
\hline RWR 10 avg & Adult & 2.0 & $-10.1 \pm 0.8$ & $-0.3 \pm 0.6$ & 0.7091 & Coastal & LA & 19 \\
\hline RWR 13 avg & Juvenile & 1.1 & $-10.7 \pm 0.6$ & $2 \pm 0.7$ & - & Coastal & LA & 2 \\
\hline RWR 17 avg & Subadult & 1.3 & $-12.6 \pm 1.1$ & $1.4 \pm 1.2$ & 0.7092 & Coastal & LA & 3 \\
\hline RWR 21 avg & Juvenile & 0.9 & $-15.1 \pm 0.8$ & $-0.8 \pm 0.0$ & - & Coastal & LA & 2 \\
\hline RWR 28 avg & Subadult & 1.3 & $-11.1 \pm 1.6$ & $1.9 \pm 0.2$ & - & Coastal & LA & 2 \\
\hline RWR 30 avg & Adult & 2.4 & $-12.9 \pm 0.1$ & $-1 \pm 0.8$ & 0.7095 & Coastal & LA & 2 \\
\hline UF 35153 avg & Adult & na & $-9.3 \pm 0.3$ & $-1.4 \pm 0.4$ & - & Coastal & LA & 3 \\
\hline UF $10941 \mathrm{avg}$ & Adult & na & $-13.6 \pm 4.8$ & $-0.4 \pm 0.1$ & 0.7093 & Coastal & S. FL & 2 \\
\hline UF 9225 & Adult & na & $-15.5 \pm 0$ & $-0.3 \pm 0$ & - & Inland & N. FL & 1 \\
\hline UF 34886 & Adult & na & $-17.4 \pm 0$ & $-0.5 \pm 0$ & - & Inland & N. FL & 1 \\
\hline UF 42548B & Adult & na & $-13 \pm 0$ & $-3.5 \pm 0$ & 0.7085 & Inland & N. FL & 1 \\
\hline UF $42872 B$ & Adult & na & $-11.6 \pm 0$ & $-4.5 \pm 0$ & 0.7101 & Inland & S. FL & 1 \\
\hline UF $105541 \mathrm{avg}$ & Adult & na & $-17.1 \pm 0.4$ & $0.4 \pm 0.7$ & - & Inland & S. FL & 3 \\
\hline UF 84197 avg & Adult & na & $-16.7 \pm 1.0$ & $-1.2 \pm 1.7$ & - & Inland & S. FL & 3 \\
\hline UF 87886 avg & Adult & na & $-17 \pm 1.0$ & $1.2 \pm 1.2$ & 0.7093 & Inland & S. FL & 3 \\
\hline UF 98341 & Adult & na & $-17.6 \pm 1.0$ & $-1 \pm 0.4$ & - & Inland & S. FL & 3 \\
\hline UW G1 & Subadult ${ }^{\mathrm{b}}$ & na & $-15.6 \pm 0$ & $0.7 \pm 0$ & - & Inland & S. FL & 1 \\
\hline UW G2 & Subadult ${ }^{\mathrm{b}}$ & na & $-16.3 \pm 0$ & $2.5 \pm 0$ & 0.7091 & Inland & S. FL & 1 \\
\hline UW G3 & Subadult ${ }^{\mathrm{b}}$ & na & $-15.4 \pm 0$ & $2.4 \pm 0$ & 0.7091 & Inland & S. FL & 1 \\
\hline UW G4 & Subadult $^{\mathrm{b}}$ & na & $-15.7 \pm 0$ & $1.6 \pm 0$ & - & Inland & S. FL & 1 \\
\hline \multicolumn{9}{|l|}{ C. acutus } \\
\hline UF 33655 avg & Adult & na & $-10.9 \pm 0.1$ & $1.1 \pm 0.5$ & - & Coastal & S. FL & 2 \\
\hline UF 54201 avg & Adult & na & $-8 \pm 0.3$ & $0.3 \pm 0.6$ & 0.7092 & Coastal & S. FL & 4 \\
\hline UF 56428 avg & Adult & na & $-6.8 \pm 0.4$ & $0.6 \pm 0.4$ & - & Coastal & S. FL & 2 \\
\hline UF 56429 avg & Adult & na & $-2.5 \pm 1.6$ & $1.4 \pm 0.2$ & - & Coastal & S. FL & 4 \\
\hline UF 56580 avg & Adult & na & $-14.5 \pm 0.9$ & $-0.4 \pm 0.3$ & 0.7095 & Coastal & S. FL & 3 \\
\hline UF 63929 avg & Adult & na & $-14.3 \pm 1.0$ & $1.12 \pm 0.8$ & - & Coastal & S. FL & 3 \\
\hline UF 66034 avg & Adult & na & $-8.3 \pm 0.0$ & $0.4 \pm 0.3$ & - & Coastal & S. FL & 2 \\
\hline UF 98068 avg & Adult & na & $-8.3 \pm 1.4$ & $1.2 \pm 1.2$ & - & Coastal & S. FL & 4 \\
\hline UF 56671D & Adult & na & $-12.8 \pm 0$ & $-1 \pm 0$ & 0.7094 & Coastal & S. FL & 1 \\
\hline
\end{tabular}


Appendix 2. Information from an individual versus the population

Because crocodylians replace their teeth continuously, it is possible that analysis of multiple teeth from 1 individual could supply as much information about a population as analysis of a single tooth from multiple individuals, assuming that the individual behaved in a manner that was representative of the population as a whole. There is growing recognition of the importance of individual specialization, however, in shaping the ecology of a population and the dynamics of food webs (Bolnick et al. 2003). Furthermore, crocodylians can travel large distances (Rodda 1984, Kushlan \& Mazzotti 1989, Kay 2004, Brien et al. 2008), and mere proximity does not ensure similarity in diet, migratory habits, or other aspects of ecology. To assess the possibility of using multiple teeth from single individuals to bolster sample size, we analyzed the $\delta^{13} \mathrm{C}$ and $\delta^{18} \mathrm{O}$ values of teeth from 14 alligators from Rockefeller Wildlife Refuge (RWR) in coastal Louisiana (Table A2). For 1 alligator (RWR 10), we analyzed 19 teeth (Table A3), and then compared within-individual to within-population variance. RWR 10 was included in the population statistics, but the values from the 19 teeth were averaged to give a single value for that individual. Two-sample $F$-tests for variance were performed for $\delta^{13} \mathrm{C}$ and $\delta^{18} \mathrm{O}$ values. In both statistical analyses, $\mathrm{p}<0.01$, indicating that the level of variance present in the 2 populations is different. Isotopic values from multiple samples from 1 individual were significantly less variable than values for single teeth from different individuals. Therefore, it is not reasonable to bolster sample size by incorporating multiple teeth from the same individual.

Table A2. Alligator mississippiensis. Isotope data from 14 individual alligators from Rockefeller Wildlife Refuge (RWR), Louisiana (note UF specimen was collected at RWR but is curated at the University of Florida)

\begin{tabular}{|lcc|}
\hline Individual & $\delta^{13} \mathrm{C}(\%)$ & $\delta^{18} \mathrm{O}(\%)$ \\
\hline RWR 2 & -8.2 & -0.9 \\
RWR 3 & -7.6 & -1.8 \\
RWR 4 & -7.0 & -2.3 \\
RWR 5 & -12.1 & -3.1 \\
RWR 6 & -7.7 & -1.7 \\
RWR 7 & -12.2 & -3.8 \\
RWR 8 & -7.3 & -1.9 \\
RWR 9 & -7.6 & 0.3 \\
RWR 13 & -10.7 & 2.0 \\
RWR 21 & -15.1 & -0.8 \\
RWR 28 & -11.1 & 1.9 \\
RWR 30 & -12.9 & -1.0 \\
UF 35153 & -9.3 & -1.4 \\
RWR 10 (mean) & -10.1 & -0.3 \\
Mean & -9.9 & -1.1 \\
SD & 2.5 & 1.7 \\
\hline
\end{tabular}

Editorial responsibility: Yves Cherel, Villiers-en-Bois, France
Table A3. Alligator mississippiensis. Isotope data from 19 teeth from 1 individual alligator from Rockefeller Wildlife Refuge (RWR)

\begin{tabular}{|lcc|}
\hline Tooth & $\delta^{13} \mathrm{C}(\%)$ & $\delta^{18} \mathrm{O}(\%)$ \\
\hline RWR 10A & -8.9 & -0.9 \\
RWR 10B & -10.1 & -0.8 \\
RWR 10C & -11.1 & 1.7 \\
RWR 10D & -9.4 & 0.3 \\
RWR 10E & -9.6 & -0.3 \\
RWR 10F & -9.8 & -0.6 \\
RWR 10G & -9.4 & -0.8 \\
RWR 10H & -9.5 & -0.5 \\
RWR 10I & -9.5 & -0.6 \\
RWR 10J & -10.2 & -0.3 \\
RWR 10K & -11.1 & -0.4 \\
RWR 10L & -11.1 & -0.6 \\
RWR 10M & -10.0 & -0.1 \\
RWR 10N & -9.2 & -0.5 \\
RWR 10O & -9.9 & 1.0 \\
RWR 10P & -11.5 & -0.5 \\
RWR 10Q & -10.4 & -1.3 \\
RWR 10R & -10.3 & -0.5 \\
RWR 10S & -11.4 & -0.2 \\
Mean & -10.1 & -0.3 \\
SD & 0.8 & 0.6 \\
\hline
\end{tabular}

Submitted: October 11, 2010; Accepted: November 12, 2011 Proofs received from author(s): February 6, 2012 